Canadian Journal of Fisheries and Aquatic Sciences Journal canadien des sciences halieutiques et aquatiques

\title{
Life history variation across four decades in a diverse population complex of Atlantic salmon in a large subarctic \\ river
}

\begin{tabular}{|c|c|}
\hline Journal: & Canadian Journal of Fisheries and Aquatic Sciences \\
\hline Manuscript ID & cjfas-2017-0343.R2 \\
\hline Manuscript Type: & Article \\
\hline Date Submitted by the Author: & 27-Feb-2018 \\
\hline Complete List of Authors: & $\begin{array}{l}\text { Erkinaro, Jaakko; Natural Resources Institute Finland, } \\
\text { Czorlich, Yann; Natural Resources Institute Finland } \\
\text { Orell, Panu; Natural Resources Institute Finland (Luke), } \\
\text { Kuusela, Jorma; Natural Resources Institute Finland } \\
\text { Falkegărd, Morten; Norsk Institutt for Naturforskning, Department for } \\
\text { Arctic ecology } \\
\text { Länsman, Maija; Natural Resources Institute Finland } \\
\text { Pulkkinen, Henni; Natural Resources Institute Finland (Luke) } \\
\text { Primmer, Craig; Helsingin yliopisto Matemaattis-luonnontieteellinen } \\
\text { tiedekunta, Department of Biosciences, Biotechnology Institute } \\
\text { Niemelä, Eero; Natural Resources Institute Finland, }\end{array}$ \\
\hline $\begin{array}{r}\text { Is the invited manuscript for } \\
\text { consideration in a Special } \\
\text { Issue? : }\end{array}$ & N/A \\
\hline Keyword: & $\begin{array}{l}\text { LIFE HISTORY < General, MONITORING < General, SALMON < Organisms, } \\
\text { MATURATION < General, BIODIVERSITY < General }\end{array}$ \\
\hline
\end{tabular}

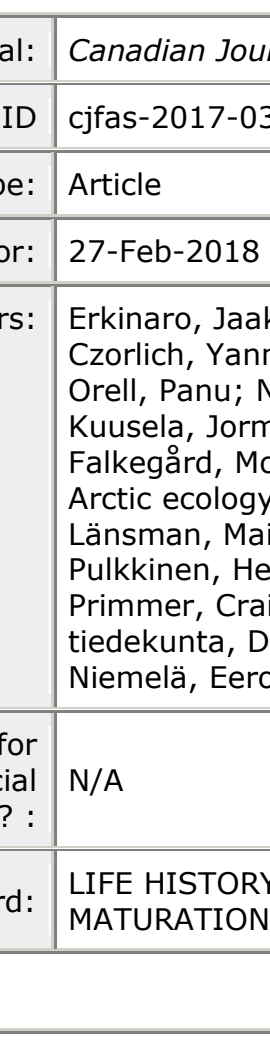

\section{SCHOLARONE \\ Manuscripts}




\section{Life history variation across four decades in a diverse population complex of 2 Atlantic salmon in a large subarctic river}

3

4

5

6

7

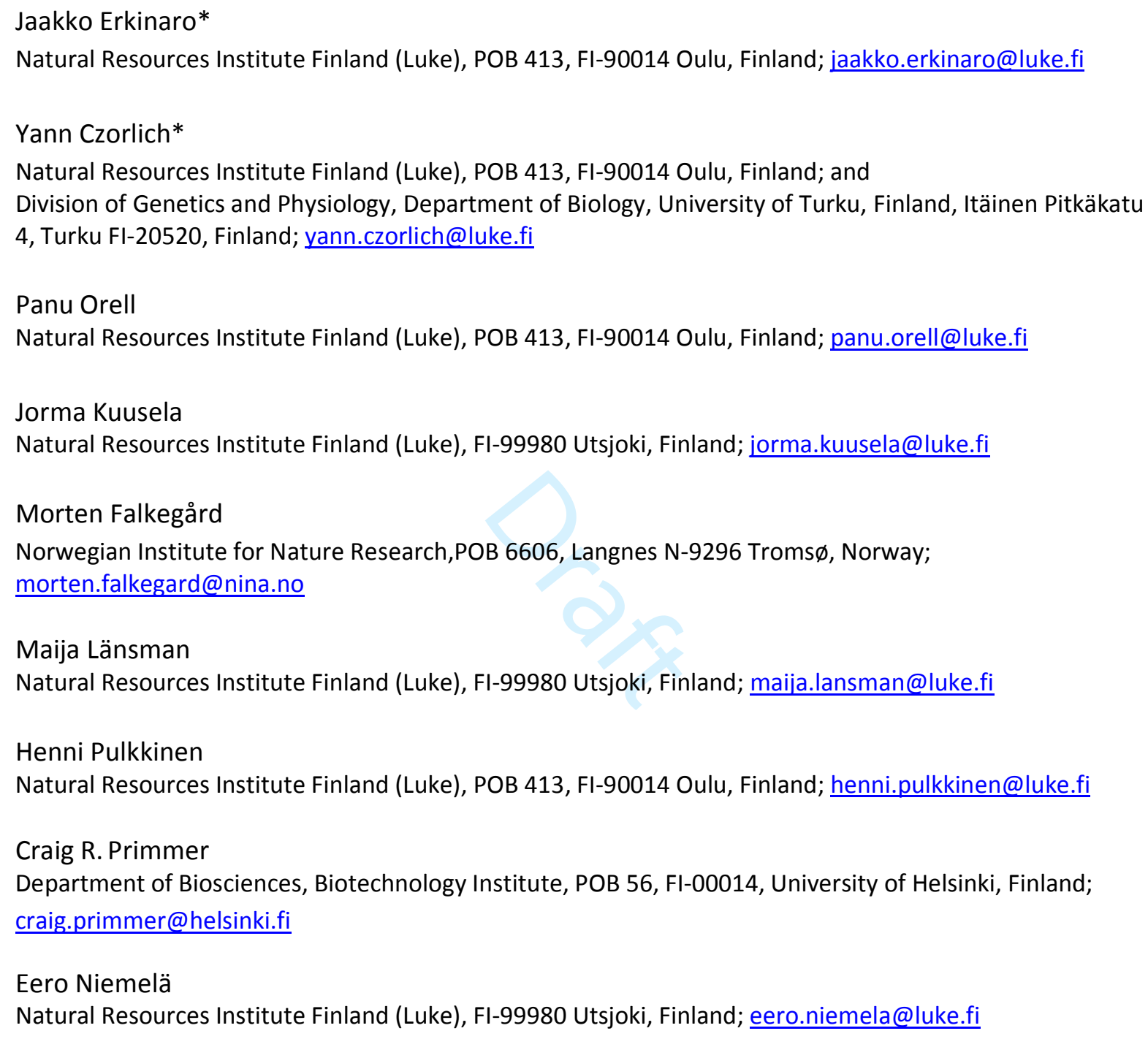


42

43

44

45

46

47

48

49

50

51

52

53

54

55

56

57

58

59

60

61

62

63

64

65

\section{Abstract}

We used >154000 scale samples collected from salmon fisheries in the large River Teno system over a 40year period to quantify life history diversity and long-term trends. We identified 120 different life history strategies including combinations of smolt (2-8) and sea ages (1-5) and previous spawning events. Most strategies were rare: $60 \%$ of individuals matured after one year at sea following 3-5 years in freshwater. Age at maturity has changed with an increase in two-sea-winter (2SW) salmon and previous spawners (PS), and a decline in 3SW fish. Smolt age distribution showed a decreasing proportion of age-3 smolts while that of age- 5 increased. Fishing gear and fishing season times selected for fish differing in life-history strategies. Temporal variation in life histories reflects changes both in fisheries and the changing environment. There was an inverse relationship between years spent in freshwater and sea age. Biocomplexity was manifested by the multiple year classes (6-11) present in annual runs that increased with years, reflecting an increase both in PS and sampling effort. The high number of cohorts spawning simultaneously each year indicates strong generation overlap, which has been suggested to maintain genetic diversity and thereby resilience via the portfolio effect.

\section{Introduction}

Bio-complexity in fish populations, i.e. their diversity and variation in life-history and genetic characteristics, provides resilience to disturbances by spreading risk temporally and spatially and thus contributes to long-term sustainability (Stearns 1992; Hilborn et al. 2003; Schindler et al. 2010). Sufficient diversity in populations is also a prerequisite for sustainable fisheries (Hilborn et al. 2003; Hutchinson 2008). Typically, diversity comprises variation in the age at maturity - 
individuals from the same cohort reproducing in different years - or iteroparity with the possibility of repeated spawning events for individual fish; both allocating the reproductive effort across multiple years and stabilizing populations under environmental variability (Schindler et al. 2010; Moore et al. 2014). It is therefore important to characterize the levels of, and changes in, diversity in exploited populations so that the potential importance of bio-complexity for sustaining productivity can be assessed. Such data also provide a baseline for assessing the potential effects of climate change.

Anadromous salmonid fish exhibit especially wide variation in life histories among fish species, both in time spent in freshwater before the oceanic migration and in duration of the marine feeding migration and connected timing of return migration to freshwater for spawning (e.g. Klemetsen et al. 2003). The simplest set of different salmonid life histories is that of pink salmon (Oncorhynchus gorbuscha) and the most complex those of steelhead trout (O. mykiss; Thorpe 1998; Moore et al 2014) and Atlantic salmon (Salmo salar; Klemetsen et al. 2003; Niemelä et al. 2006a).

Life history variation in Atlantic salmon is matched by few, if any, other fish species. Juvenile years of freshwater residence and the subsequent years spent at sea are the main drivers causing variation in age and size at maturity (Hutchings and Jones 1998; Klemetsen et al. 2003; Niemelä et al. 2006a). Some individuals also reach maturity in freshwater at ages between 1-5 in a size range c. 7-15 cm (Myers et al. 1986; Fleming 1996; Heinimaa and Erkinaro 2004). Anadromous life history types range from the most common group of one-sea-winter salmon (1SW; return to freshwater for reproduction after staying one winter at sea) to four- or even five-sea-winter salmon (4-5SW; e.g. Niemelä et al. 2006a). In addition, further variation in life history strategies is added by previous spawners, which return to freshwater after few months or one or more years of 
reconditioning period at sea after the previous spawning migration (e.g. Niemelä et al. 2006a;

Chaput and Benoît 2012).

The abundance of Atlantic salmon has declined markedly throughout the North Atlantic area since the 1970s (ICES 2017). Specific reasons for this continuing decline are often not clear, but multiple factors are likely responsible (Friedland et al. 2009; Chaput 2012). A loss of phenotypic diversity has also been reported, namely a general decline in age at maturity, although marked variation exists between rivers and regions (Klemetsen et al. 2003). Especially, a declining number of large multi-sea winter (MSW) salmon has been evident (e.g. Youngson et al. 2002; Chaput 2012), which has recently also been documented in Chinook salmon (Oncorhynchus tshawytscha) across the Northeast Pacific Ocean area (Ohlberger et al. 2018). However, in recent years an opposite trend with a decline in 1SW fish has been evident in certain areas, e.g. in Norway (Otero et al. 2012; Jonsson et al. 2016). Historically, many populations across the species' range have exhibited a wide spectrum of life histories including various smolt ages and multiple groups of sea ages of first time spawners and previous spawners, e.g. in the Baltic Sea area (Järvi 1948), Norway (Abrahamsen 1968; Jonsson et al. 1991; L'Abee-Lund et al. 2004), northwesten Russia (Studenov et al. 2008), Scotland (Shearer 1992) and eastern North America (Schaffer and Elson 1975; Saunders and Schom 1985). In addition to selective fisheries targeting large salmon (e.g. Consuegra et al. 2005; Gauthier-Ouellet et al. 2009), hatchery propagation and introgression with farmed escaped fish can reduce life-history diversity within populations and homogenize the dynamics of wild salmon populations (Moore et al. 2010; Karlsson et al. 2016; Bolstad et al. 2017).

Given the widespread losses of salmon population diversity and the extent to which river systems are affected by anthropogenic threat factors, it is important to assess diversity in river systems that are still relatively intact. The large Teno river system in northernmost Europe is 
112

characterized by remarkable genetic (Vähä et al. 2007; 2008; 2017) and life history (Niemelä et al. 2006a) diversity, and has not been subjected to stocking. In the present study, we used the 40year time series of scale samples collected from adult salmon of the River Teno system to 1) quantify the life history diversity of the Teno salmon population complex as a whole and in selected sub-populations, 2) assess the long-term trends in this diversity, 3) provide guidelines for monitoring of life history diversity in large diverse population complexes and their components that are subjected to different fisheries.

\section{Material and methods}

\section{Study area}

The Teno river system (Norwegian: Tana, Sami: Deatnu) is located in northern Europe (68 $70^{\circ} \mathrm{N}, 25-27^{\circ} \mathrm{E}$ ) and forms the border between northern Finland and Norway, draining into the Tana fjord at the Barents Sea (Fig. 1). More than $1100 \mathrm{~km}$ of the different stretches of the system is accessible to anadromous salmon, including the main stem, the large headwater branches, and numerous smaller tributaries (Fig. 1). Genetic studies have revealed a highly-structured population complex consisting of c. 30 demographically independent, genetically distinct and temporally stable population segments in tributaries and different parts of the main stem (Vähä et al. 2007; 2008; 2017; Aykanat et al. 2015). The River Teno is one of the few remaining large river systems that still support multiple and abundant wild Atlantic salmon populations; various forms of recreational and net fisheries in the river yield annual freshwater catches between 80 and 250 tons, or 20 000-60 000 individual salmon (Niemelä et al. 2006a; Anon. 2018). Typically, the majority (50-60\%) of the salmon catch is taken in the recreational rod fishery, the next most 
important gears being weir (c. 20\%) and stationary gill nets (10-20\%), and the smallest proportion (c. 10\%) being taken with drift nets (Anon. 2016). The net fisheries are practiced by locals, mostly native Sámi, and are based on special fishing rights connected to land use, ownership or inherited rights.

In addition to the extensive fishery in the main stem, salmon fishing is also operational in most of the tributaries, but there is less variation in fishing methods in the latter. In most tributaries, little or no net fishing is operated or allowed, although in some larger tributaries net fishing forms a significant share of the catch. A special management regime is practiced in the River Pulmankijoki (Fig 1) where all salmon fishing takes place in a central lake by gill nets and the fluvial stretches are closed for salmon fishing.

Salmon stocks of the Teno system are managed and fisheries regulated by bilateral agreements between Finland and Norway, in addition to national regulations in both countries, with the aim at conserving the wild stocks but also supporting sustainable fisheries. Stocking of reared fish or eggs is strictly forbidden in the Teno system.

\section{Scale samples and their analyses}

More than 154000 scales were collected from Atlantic salmon harvested over a 40-year period (1975-2014) in the Teno river system (Table S1) by recreational tourist anglers and local fishers using various net and rod fishing methods (see above; Fig 2). The scales were collected by a network of trained fisherman, equipped by standard measuring boards and scales, and was established by the Finnish Game and Fisheries Research Institute (currently: Natural Resources Institute Finland (LUKE)) in the 1970s, and later complemented on the Norwegian side by the County Government of Finnmark and the Tana River Fish Management. The network has been 
maintained and developed with the aim at covering all fishing methods, the entire fishing season, and different parts of the Teno river system (cf. Niemelä et al. 2005; 2006a). The fishermen measured the length and weight of the fish in their catches, and recorded the sex of the fish, date of capture, and location and fishing gear used. Scales were dried and archived in paper envelopes at room temperature at the Teno River Fisheries Research station of LUKE in Utsjoki, Finland.

The river and sea age (1SW: one-sea-winter salmon; 2SW: two-sea-winter salmon etc.) and possible previous spawning history of each individual were determined via assessment of scale growth rings by trained, experienced experts, following the internationally agreed guidelines for Atlantic salmon scale reading (ICES 2011). Annually, a small number of escaped farmed salmon are captured and sampled in the Teno river fishery in addition to the wild salmon (Erkinaro et al. 2010). The farmed salmon were distinguished by the external characteristics by fishermen, and later confirmed by scale growth patterns consistent with their history of captive rearing (Fiske et al. 2005). Farmed salmon were excluded from the present study. The total weight of yearly salmon catches was estimated from postal questionnaires sent to fishermen, interviews and logbooks, and then converted into estimated numbers of fish in catch using the sea-age distribution of yearly catch samples (cf. Niemelä et al. 2005), weighted by user groups in different parts of the system, which reflects the main gear types and parts of the fishing season used by each group of fishers.

\section{Samples were collected both in the fishery of the main stem and from tributaries. We selected} a representative set of tributaries for this study from different parts of the river system that had the longest time series data and sufficient numbers of samples available per year. These tributaries include (from lower to the upper part of the system) Máskejohka, Pulmankijoki, Vetsijoki, Utsjoki, Kuoppilasjoki, Inarijoki, Kárášjohka and lešjohka (Fig. 1). In addition, the samples collected along the c. $210 \mathrm{~km}$ long main stem were separated to form two separate groups, 
termed here lower (from the estuary up to Norwegian-Finnish border; $60 \mathrm{~km}$ ), and upper (from the border to the junction of Inarijoki and Kárášjohka; 150 km) part of the main stem (Fig. 1).

In the absence of catch quotas and monitoring of the total number of salmon entering the Teno river, the total salmon catch is considered to represent a reasonable index of abundance (cf. Niemelä et al. 2005; Thorley et al. 2005). There are significant correlations in the catch between fishing methods, indicating that - in general - environmental conditions are stable enough to allow effective fishing for all fishing methods in different parts of the system throughout the season. In addition, we have detected correlations between run size and catch in monitoring programmes at tributaries of the Teno (Anon 2018; unpublished data). Therefore, we use here catches as indices reflecting run sizes (Niemelä 2004; Niemelä et al. 2009).

\section{Statistical methods}

Life-history strategy diversity was quantified by evaluating unique combinations of years spent in freshwater and in the ocean, and the number of reproductive events. An individual-based rarefaction curve with 95\% unconditional confidence intervals was used to determine the relationship between the number of strategies described and the number of individuals sampled throughout the 40-year period. After rank-ordering life-history strategies by their frequencies, the proportion of each strategy was plotted against its rank. Temporal variation in numbers of strategies between 1975 and 2014 was visualized by building individual-based rarefaction and extrapolation curves for each 5-year period (cf. Chao et al. 2014). Variation in strategy diversity among rivers was determined by comparing raw richness along with sampling effort and estimated Hill number of order 1 (Hill 1973). Hill number of order 1 represents the exponential of Shannon's entropy and weights strategies according to their frequency. This index is sensitive to 
201

202

203

204

205

206

207

208

209

210

211

212

213

214

sampling size and was extrapolated with $95 \%$ unconditional confidence intervals obtained by bootstrapping following Chao et al. (2014).

The main components of the life-history strategy, sea-age and river-age, were assessed separately for trends across time and space. Sea-age includes the reproductive status of salmon (first time or repeat spawner) and the time spent at sea before maturation. The proportion of the main sea-age groups, 1-3 sea-winter (1-3SW) and previous spawners (representing more than $99 \%$ of individuals), were analyzed with separated generalised linear models, using the quasibinomial family to account for overdispersion. The year, month and location of capture, the fishing gear used and the sex of each individual were included as independent variables, along with the oneyear lagged dependent variable in order to remove autocorrelation in residuals. A two-way interaction between sex and month and a three-way interaction between the year, location and sex were also introduced as explanatory variables. Model selection was performed with a hypothesis testing approach using backward selection with $\mathrm{F}$ tests. Post-hoc analyses were performed using Wald tests with Bonferroni adjustment of $p$-values for pairwise comparisons. Mean values displayed in the different figures are "least-squares means" (cf. Lenth 2016).

Proportions of the three most frequent smolt age groups ( 3 to 5 years; representing more than $96 \%$ of individuals) were analysed separately with generalised additive models (GAM), using the quasibinomial family. The location of capture and age at sea were included as independent variables together with the year of smoltification, inside a smoothing function using cubic regression splines. This allowed determination of eventual non-linear variations in proportions of smolt age groups over years. Cross-validation was used to determine the optimal amount of smoothing. The significance of explanatory variables and smoothing term were assessed using Ftests. 
Analyses were performed using the R software (R Core Team 2015), the INEXT package for the rarefaction curves and the estimations of Hill numbers (Hsieh et al. 2015) and the mgcv package for the generalised additive models (Wood 2011). An alpha risk of 0.05 was used for all analyses.

\section{Results}

Large diversity in life histories in the Teno system

A total of 120 life-history strategies were quantified over the 40 -year period including smolt ages ranging from 2-8, maiden sea ages from 1-5, and a variety of previous spawners. Twenty-nine different strategies were maiden salmon, 54 alternate spawners (two or more years between spawning migrations) and 37 consecutive spawners (spawning migrations in consecutive years), i.e. $69 \%$ of strategies belonged to repeat spawners. Hence, most life history strategies were rare

(Fig. 3). One quarter of the total number of strategies were identified only once whereas the five most common strategies comprised $79 \%$ of the individuals sampled. The most common combinations were 4-1 (river age - sea age; 49992 individuals; 35\% of samples), 5-1 (24 276; 17\%), 3-1 (15407; 11\%), 4-2 (12 280; 9\%), 4-3 (10 090; 7\%). Although the sampling effort was relatively high, the rarefaction curve did not reach an asymptote (Fig 3) and new rare strategies could potentially still be discovered by increasing the number of samples.

Rarefaction and extrapolation analysis revealed changes in richness of life-history strategies throughout the 40-year period studied (Fig. 4). Curves for the first 20 years (1975-1989) were similar and strategies were accumulated less rapidly than during the last 20 years (1990-2014), mostly driven by a sharp increase in previously spawned salmon during the latter period (Fig. 5). 
Rarefaction curves for the later time period show that the highest strategies richness was reached in 2000-2009 before a significant reduction during the last five-year period (2009-2014).

The number of strategies observed differed largely among different parts of the River Teno system (Fig 6), ranging from 15 in Kuoppilasjoki to 116 in the Teno mainstem. Scale samples collected in the lowermost Norwegian part of the Teno mainstem did not add much to the total diversity of strategies observed in the river system until the sampling effort increased substantially from 1998. Over the last 17 years, 1998-2014, the number of strategies observed would have been reduced on average by six without samples from the lower part of the main stem (Norway only) and nine without those from the upper part (Finnish-Norwegian border zone), representing 13\% and $18 \%$, respectively, of the annual mean number of strategies characterized during this period. Without the samples from the upper part of the main stem, the total number of life-history strategies observed over the 40 years period would have been 94 instead of 120, and 110 without the lower side. Thus, the bilateral collaboration in sampling has been useful.

Sampling effort varied a lot between the locations; for instance Kuoppilasjoki and Teno main stem accounted for $0.3 \%$ and $73 \%$ of the total number of scale samples collected, respectively. Despite the vast differences in sampling effort, Hill numbers of order 1 could be estimated quite precisely and provided a better view of differences in diversity once rare elements were downweighted (Fig. 6). The Teno mainstem and the large headwater rivers, Kárášjohka and lešjohka, had the highest diversity with Hill numbers as high as 12, followed by Máskejohka with a Hill number slightly below eight. The other locations showed Hill numbers between four and five indicating a markedly less diversity for those areas compared to the Teno main stem, for instance

(Fig 6). The number of salmon year classes (hatching year) in annual catches increased from 6-8 in 
1979s - late 1980s to 8-11 in 2000s and 2010s (Fig. 7) thus indicating that multiple year classes contribute to reproduction in the Teno system each year.

\section{Variation in sea-age groups}

Annual catches fluctuated greatly between 1975 and 2014, with a maximum as high as 61,800 individuals estimated in catches in 2000 (Fig. 5). However, variation in catches has been lower in the 10 last years. Overall, $59 \%$ of the salmon caught were 1 SW fish whereas $5 \%$ were previous spawners (PS There was a marked negative trend in abundances of both 3SW and 4-5SW groups across the time series, whereas $2 \mathrm{SW}$ fish and previous spawners showed an increasing trend (Fig. $5)$.

The year, month, location and method of capture together with sex of fish significantly influenced the observed sea-age proportions in catches, sometimes in complex ways. Most of the explanatory variables and their two-way interactions were significantly associated with the proportions of the four sea age groups analyzed (1-3 SW and PS) despite some differences among models (Table 1). The three-way interaction between year, location and sex was not a significant predictor of sea-age proportions in any model (Table 1). The most obvious examples include the strong association between the proportion of 3SW salmon and time (negative trend over the years).

There was considerable temporal variation in the proportions of the different sea-age groups in different areas of the River Teno system (Fig. 8). Estimated slopes representing changes in odds of being $1 \mathrm{SW}$ across the 40 -year time period were below 1 for both sexes in all locations except for females in the Teno main stem (Fig. S1). For the Teno main stem, the proportion of 1SW female significantly increased whereas it significantly decreased in Inarijoki and Utsjoki. For males, the 
289

290

291

292

293

294

295

proportion of 1SW individuals significantly decreased in Inarijoki, Pulmankijoki, Utsjoki and in the Teno main stem (Fig. 8). The proportion of 2SW individuals increased across the 40 -year time period in all locations, with significantly different slopes between sexes (females 1.018 with $95 \% \mathrm{Cl}$ $=[1.013,1.023] ;$ males $1.042[1.033,1.052])$. For 3SW individuals, an overall significant decrease was observed $(0.970[0.965,0.974])$. Proportions of repeat spawners increased significantly in the Teno main stem, Utsjoki and Inarijoki with slopes ranging from $1.034([1.027,1.040])$ in the mainstem to $1.059([1.026,1.093])$ in Inarijoki.

Spatial variation in proportions of $1 \mathrm{SW}$ was higher for females, although tributaries with the largest proportions of 1SW females had also generally the largest proportions of 1SW males (Fig. 9). Differences in 1SW proportions among locations were large; for instance, the proportions of 1SW females and males in Utsjoki were more than three and 1.2 times higher, respectively, than in lešjohka ( $Z=-3.63, p=0.01$ and $Z=-3.32, p=0.03$, respectively). Considerable proportions of 3SW - mostly female - salmon were found in the main stem and in the large headwater branches, Kárášjohka and lešjohka, while other large tributaries like Máskejohka, Vetsijoki and Inarijoki also comprised considerable proportions of 2SW female fish (Fig. 9)

$$
\text { The month of fishing season influenced sea-age composition in catches: for instance, the }
$$
proportions of 1SW individuals in July-August were larger than in May-June for both sexes (Fig. 10; $\mathrm{p}<0.0001)$. In contrast, the proportion of previous spawners was much higher in May-June than in July-August (4.3-3.6 fold more in males and 2.2-1.5 fold in females; Fig. 10). Different fishing gear appeared to select for different sea-age groups. The highest proportions of 1SW were captured with weir, followed by rod, gillnet and driftnet (Fig. 11, pairwise p-values $<0.001$ ). The mean proportion of $1 \mathrm{SW}$ in rod catches was more than double of that in driftnet catches, which in turn 
311

312

313

314

315

316

317

captured significantly more 2-3SW salmon and previous spawners than the other methods (Fig. 11).

\section{Variation in river-age}

Temporal trends in different river age groups were non-linear (effective degrees of freedom of smoothers $>18, p<0.001)$. The proportion of three-year-old smolts decreased over the first 30 years whereas the proportion of five-year-old smolts increased (Fig. 12). The proportion of fouryear-old smolts fluctuated around its mean and the magnitude of the smooth function range was low in comparison with the two other river age groups analyzed. Some changes in general patterns could be noticed: after 2000 , the fluctuations in the proportions of age-3, 4 and 5 smolts decreased drastically (Fig. 12). For each analysis, the location within the Teno catchment had a significant influence on proportions of the different age groups ( $p$ values $<0.001 ;$ Fig. 13). Individual standard errors were quite high and did not allow distinguishing locations with particular age at smoltification except for the River Kuoppilasjoki where smolts were generally older, with $82 \%$ of the salmon caught having smoltified after a minimum of 5 years (Fig. 13).

Proportions of smolt ages differed between sea age groups $(p<0.001)$ : a three year smoltification age in freshwater was more common in 3SW and 4SW than in 1SW and 2SW (odds for $3 S W$ and $4 S W 44 \%$ and $84 \%$ higher, respectively, than for 1-2SW) groups. 1-2SW salmon showed the highest odds of having smoltified after five years in river (odds 54\% and 101\% larger, respectively, than for $3 S W$ and 4 SW, Fig. 14). The proportions of salmon smoltifying at the age of four years were similar among all sea age groups $(\mathrm{df}=4, \mathrm{~F}=1.36, \mathrm{P}=0.25$; Fig. 14).

\section{Discussion}


The Atlantic salmon population complex of the River Teno show an unusually wide life-history variation in combinations of smolt ( $2-8$ years) and sea ages ( $1-5$ years) in maiden fish, and in various forms of alternate and consecutive spawners, comprising 29, 54 and 37 combinations, respectively, totaling 120 different manifestations of the anadromous life-history strategy. This diversity is among the widest, if not the widest, reported in a single river system in the distribution area of the species. The oldest salmon recorded was a 14 year old female $(122 \mathrm{~cm}, 17.0 \mathrm{~kg})$ with four previous spawning migrations and a total of six years spent at sea.

There are some areas of the species' distribution range where Atlantic salmon populations also exhibit wide ranges of life history characteristics. Chaput et al (2006) summarized the phenotype characteristics of more than 100 salmon rivers in eastern Canada, and documented a smolt age range of 1 to 7 years, sea ages 1-4 years, and Reid and Chaput (2012) reported additional variety of life histories of previously spawned salmon (PS) in that area (see below). In the large Pechora River, northwestern Russia, a total of 24 life history combinations have been reported (Studenov et al. 2008), and many Russian northwest rivers include autumn-migrating salmon that spend one full year in freshwater before spawning (e.g. Whoriskey et al. 1996; Studenov et al. 2008). The large diversity of life history strategies like in the Teno system is nevertheless extraordinarily rare or unique in single river systems or areas (e.g. Klemetsen et al 2003; Jonsson and Jonsson 2011).

The vast majority of all life history strategies in the River Teno system were in the diverse group of previously spawned salmon (PS). The abundance and proportion of PS is a function of maiden salmon one or more years earlier; environmental conditions together with fishing pressure are affecting the survival of spent fish in the river and during their migration to and at sea, and their survival back to freshwater (Klemetsen et al 2003; Chaput and Benoît 2012). The contribution of PS showed a marked increase around the turn of the millennium (Fig. 5), and Niemelä et al (2006a) 
have earlier discussed the reasons behind this development. Cessation of the highly size-selective drift net fishery off the northern Norwegian coast in 1988 was followed by an increase in both 2SW and PS salmon in the rivers in the Barents Sea area (Jensen et al. 1999). However, despite the large run of 1SW salmon in 1990-1991, the corresponding increase of PS salmon was not especially clear, but the second peak in 1SW abundance in 2000-2001 resulted in an unpreceded abundance of PS salmon in the Teno system (Niemelä et al. 2006a), although the coastal catches were generally higher in the latter period (Niemelä et al. 2012). Since environmental conditions in the Barents Sea have shown to be correlated with the variation in salmon catches in the region (Niemelä et al. 2004; Pasanen et al. 2017), it has been speculated that the increased surface temperature at the Barents Sea between 1990s and 2000s may have contributed to the better survival of kelts and improved prospects for abundant returns of PS salmon in early 2000s (Niemelä et al. 2006a). In addition, a general peak in salmon abundance was evident at the turn of the Millennium (Anon. 2017; ICES 2017).

In addition to the Barents Sea region, the abundance of PS salmon has also recently increased in the north-western Atlantic area (cf. Klemetsen et al. 2003), especially in the large Miramichi river running to the Gulf of St. Lawrence (Reid and Chaput 2012). At least 20 different PS strategies have been found in the Miramichi river (Reid and Chaput 2012) with more than $50 \%$ contribution of consecutive spawners (spawning migration in consecutive years; Chaput and Benoît 2012) whereas the alternate spawners (reconditioning at sea for one full year or more) comprise c. $98 \%$ of the PS salmon in the Teno (this study; Niemelä et al. 2006a). Consecutive spawners are typically less common in northern areas, e.g. in northern Norway than further south (Abrahamsen 1968; Jonsson et al. 1991). Schaffer and Elson (1975) showed that probability of spending one or more full years between spawnings increases with the age at first spawning migration. Pointing towards 
a similar pattern, later studies have suggested that consecutive spawning is especially common in populations consisting mainly of 1SW spawners, whereas the proportion of alternate spawners tends to increase in populations with mainly MSW fish (Moore et al., 1995; Klemetsen et al., 2003).

The different sea age groups, including the previous spawners, showed different trends in their long-term variation. The sea age groups including the largest female spawners with the highest fecundity (Erkinaro et al. 1997; Niemelä et al. 2006a), 3-4SW salmon, showed a marked decline over the time series. This is an alarming signal and in line with the estimated stock status of the large headwater tributaries of the Teno system with populations furthest below their conservation limits, likely reflecting a long-term effect of weakening stock status of the early-running MSW salmon in Kárášjohka and lešjohka (Anon. 2018). On the other hand, 2SW salmon and previous spawners (discussed above) showed an increasing trend which can be at least partly attributed to the ban of drift nets off the Norwegian coast in late 1989 (ref. Jensen et al. 1999). There was an increasing trend of 1SW abundance until early 2000s but the latest years have shown lower abundances than 10-20 years earlier. A corresponding large-scale phenomenon has recently been noted in Norway with a decrease in the relative number of 1SW salmon and lowered growth rate. Historically, the proportion of 1SW fish among small salmon $(<3 \mathrm{~kg})$ has been very high $(92-97 \%$ in the period 1989-2006), whereas in the last decade, the corresponding percentage of 1SW fish among salmon $<3 \mathrm{~kg}$ has been $71-87 \%$ (Anon. 2017). Partly in contrast to the trends in the northeastern Atlantic area, a recent review on Chinook salmon populations in the Pacific Northwest, from Alaska to California, showed that proportions of older sea age classes have decreased over time and the length-at-age of older fish has declined while that of fish in younger sea age groups has increased (Ohlberger et al. 2018). 
402

403

404

405

406

407

408

409

410

411

412

413

414

415

416

417

418

419

420

421

422

423

424

Jonsson et al. (2016) reported recently that the proportion of 1SW Atlantic salmon in a southern Norwegian river was lower both in the 1970s and after 2000 than in the 1980s and 1990s associated with a gradual decline in post-smolt growth and smaller amounts of reserve energy in the fish. An increase in age at maturity after 2000 has also been reported from other Norwegian salmon populations (Otero et al., 2012), suggesting that this has wider relevance in eastern Atlantic populations of the species (see also ICES 2017). The recent (since early 2000s) decreasing abundance of $1 \mathrm{SW}$ salmon in the Teno system appears to be in line with this overall trend. An increase in the proportion of female $1 \mathrm{SW}$ salmon in the mixed-stock catch of the Teno main stem might reflect the improving stock status of some tributary populations consisting mostly of 1SW spawners (cf. Anon 2018).

Variability in years spent in freshwater and in the ocean in Atlantic salmon has been suggested to be a result of combined, complex effects of environment and genetic background (e.g. Hutchings and Jones 1998; Klemetsen et al. 2003; Jonsson and Jonsson 2011). Age at smoltification is likely strongly under the control of environmental factors; there is a demonstrated inverse relationship between smolt age and latitude/growth rate of juveniles (Metcalfe and Thorpe 1990;

Strothotte et al. 2005). In contrast, sea-age at maturity has been suggested to be strongly influenced by parental stock as also indicated by the relationship between ovarian development of migrating smolts and age at maturity of adult spawners (Chadwick et al. 1987). In addition, intentional selection for late maturation has proven successful both in breeding of hatchery broodstock (Glebe and Saunders 1986), and in developing cultivated strains for commercial aquaculture use (e.g. Gjøen and Bentsen 1997). Recent research has confirmed the strong genetic basis for age at maturity in Atlantic salmon; a single gene has been shown to account for c. $40 \%$ of the variation in sea age in a large number of Fennoscandian wild salmon populations (Barson et al. 
425

2015). The temporal variation in age at maturity and iteroparity of Teno salmon could result from adaptive changes and/or phenotypic plasticity following temporal differences in fishing selection and/or environmental conditions. Further studies are needed to disentangle effects of these different factors and evaluate potential consequences on dynamics and genetic diversity of the Teno salmon sub-populations.

Anadromous fish may show both short-term phenotypic responses to changes in ecosystems and climate (Jonsson et al. 2016), and long-term genetic changes in traits such as smolt age and size/age at maturity (Jonsson and Jonsson, 2011; Bal et al. 2017). Increased ocean temperatures have been particularly evident in Boreal and Arctic areas over the last decades (Hoegh-Guldberg and Bruno 2010) causing marked changes in food webs and ecosystem functioning (Kortsch et al. 2015; Frainer et al. 2017). Changes in ocean temperatures and related shifts in other physical conditions have altered marine ecosystems, and resulted in distribution shifts among oceanic fauna (Perry et al. 2005; Hátún et al. 2009). In Atlantic salmon, recent studies show that the change in ocean environment may have affected the $1 \mathrm{SW}$ salmon more than $2 \mathrm{SW}$ salmon, suggesting more critical changes in feeding conditions for young fish that have recently entered the ocean from freshwater, compared to later phases of larger salmon at sea (e.g. Bal et al. 2017 and references therein). Jonsson et al. (2016) documented a decrease in the proportion in 1SW salmon in the River Imsa, Southwestern Norway, after the peak levels around 2000 that is parallel with the trends in the present study (Fig. 8). They concluded that the long-term change in the Imsa salmon life history was mainly driven by the oceanic ecosystem change with the rebuilding of the pelagic fish abundance, together with a decrease in abundance of large zooplankton and an increase in sea surface temperature in the Norwegian Sea. Further, size-selective harvesting, where larger individuals are targeted in fishing, can result in fisheries induced evolution 
448

449

450

451

452

453

454

455

456

457

458

459

460

461

462

463

464

465

466

467

468

469

470

(Jørgensen et al. 2007; Uusi-Heikkilä et al. 2015), which may have undesirable effects on

population productivity and resilience (Law and Grey 1989; Olsen et al. 2004; Laugen et al. 2014).

However, predicting such changes is difficult due to a lack of data on the strength of selection, heritability, and genetic linkages among the traits affected (Crozier et al., 2008; Kuparinen et al. 2016).

Diverse population complexes provide more temporally stable ecosystem services; a phenomenon also referred to as the 'portfolio effect' (Greene et al. 2010; Schindler et al. 2010; Moore et al. 2014). Schindler et al. (2010) showed that the portfolio effect in sockeye salmon (Onocorhynchus nerka) resulted in a two-fold increase in catch stability in Bristol Bay, Alaska, and despite variability in environmental conditions - enabled the fishery to maintain a high productivity. This effect occurs because of asynchrony among populations in this area where even nearby populations are relatively asynchronous in their abundances and productivity, presumably influenced by differential responses to local environmental conditions (Rogers and Schindler 2008). The highly diverse salmon population complex in the River Teno may have a potential for such effect. This is in line with the suggestion put forward by Vähä et al. (2007) to explain the positive relationship between genetic diversity and the proportion of multi-sea winter salmon in Teno sub-populations. They proposed that larger generation overlap, i.e. a higher proportion of MSW individuals could reduce the impact of environmental fluctuations on a population (see also Gaggiotti and Vetter 1999). The high number of Teno salmon cohorts spawning simultaneously each year that has increased together with the increase in previous spawners over the past 20 years (up to 10-11) is also reflecting a strong generation overlap, suggested to maintain genetic diversity and thereby resilience (cf. Gaggiotti and Vetter 1999). It should be noted that the sampling effort increased well before the increase in simultaneous year classes (Table S1; Fig. 7) 
471

472

and therefore the increase of previous spawners in the Teno populations (Fig. 8) likely contributed to the strong cohort overlap spawning each year.

It is important to address a potential bias in a long time series of samples from diverse fisheries as there is a risk in changes over time, e.g. in gear proportions as it could potentially bias observed trends since there are differences in size-selectivity among gear types (cf. Jensen et al 1999). We addressed this potential bias by modeling the trends in proportions of sea age groups in order to account for such temporal variation in fishing season and gear types. The traditional net fisheries in the Teno river did not change much over the study period in terms of e.g. mesh size or net materials; it is therefore unlikely that there have been large temporal changes in gear-specific selectivity which could have affected the observed trends in sea age proportions. Typically, rod catches are considered less size-selective than net catches of Atlantic salmon (e.g. Harvey et al. 2017), and the majority of both catches and samples are from rod fisheries (Anon. 2016; this study). Although some changes have taken place in the River Teno fishing effort, e.g. the number of recreational anglers has varied with a general increasing trend (Erkinaro et al. 2017) and the number of nets has decreased (Johnsen 2010), there is no long-term change in catch proportions between the gear types (Niemelä et al. 2009; Anon. 2016). We therefore conclude that the general picture of the catch composition and its representativeness have changed minimally over the decades and that covering the different fishing gears and times of the fishing season should provide a reasonably accurate overall picture of the life history variation in the population.

The large variation in the Teno salmon life histories offers opportunities and a safeguard for the genetic contribution of each year class over a number of subsequent spawning years. Successful management is of vital importance in enabling and conserving this diversity, and targeted measures, e.g. regulations in the early season fishery, can be used to conserve specific groups such 
494

as 2-4SW fish that largely consist of large, high-fecundity females (Niemelä et al. 2006b) that potentially produce offspring with higher survival due to their eggs having higher lipid content (Heinimaa and Heinimaa 2004). Early season regulations also safeguard previous spawners that often make a substantial proportion of the large female spawners in small tributaries dominated by 1SW salmon (Fig. 9; Niemelä et al. 2006b). Such tailored management measures have already been applied in the recent bilateral agreement on the Teno salmon fishery between Finland and Norway (Anon. 2018) that makes use of detailed information on spatial and temporal variability in populations, life history groups, and selectivity of different fishing gear in the mixed stock catches in the Teno main stem (Vähä et al. 2017).

Long-term monitoring programmes on a large and variable population complexes, like Atlantic salmon from the Teno system, require a representative coverage of different parts of the river system, times of the fishing season, and various fishing methods. Our results clearly indicate that covering the entire fishing season is necessary e.g. in capturing the large diversity in early running previously spawned salmon (cf. Niemelä et al. 2006b). In addition, the genetically distinct subpopulations with variable life history combinations have specific run-times (Vähä et al. 2011), which further adds to the necessity to cover all run times. The variety of different fishing gear types at use in the Teno system is also a source of variability. Combined with the specific peak seasons for most gear types (e.g. drift nets only permitted in early season), covering the fishing methods should be linked with the temporal considerations in planning a strategy for monitoring and sampling. Finally, the combined sampling efforts of both countries sharing the catchment seemed to ensure capturing a good representation of the various life history types. 
We thank the numerous fishers and their background organizations in the Teno river system who have helped collecting the large data set over the 40 years; Jari Haantie, Jorma Ollila and Matti Kylmäaho for analyzing scale material and two anonymous reviewers for helpful comments. Funding was partly provided by the Academy of Finland (project No. 286334).

\section{References}

Abrahamsen, B. 1968. Undersökelser over laks i Finnmark. Jakt-fiske-friluftsliv 9: 1-12.

Anon. 2016. Status of the River Tana salmon populations 2016. Report of the Working Group on Salmon Monitoring and Research in the Tana River System. Available from https://www.luke.fi/wpcontent/uploads/2017/05/2016 Tana status report final.pdf population. Mol. Ecol. 24: 5158-5174. 
Bal, G., Montorio, L., Rivot, E., Prevost, E., Bagliniere, J.L., and Nevoux, M. 2017. Evidence for long-term change in length, mass and migration phenology of anadromous spawners in French Atlantic salmon Salmo salar. J. Fish Biol. 90: 2375-2393.

Barson, N., Aykanat, T., Hindar, K., Baranski, M., Bolstad, G., Fiske, P., Jacq, C., Jensen, A., Johnston, S., Karlsson, S., Kent, M., Moen, T., Niemelä, E., Nome, T., Naesje, T., Orell, P., Romakkaniemi, A., Saegrov, H., Urdal, K., Erkinaro, J., Lien, S., and Primmer, C. 2015. Sex-dependent dominance at a single locus maintains variation in age at maturity in salmon. Nature 528: 405-408.

Bolstad, G. H., Hindar, K., Robertsen, G., Jonsson, B., Sægrov, H., Diserud, O. H., Fiske, P., Jensen, A. J., Urdal, K., Næsje, T. F., Barlaup, B. T., Florø-Larsen, B., Lo, H., Niemelä, E., and Karlsson, S. 2017. Gene flow from domesticated escapes alters the life history of wild Atlantic salmon. Nat. Ecol. Evol. 1, 0124.

Chadwick, E. M. P., Claytor, R. R., Léger, C. E., and Saunders, R. L. 1987. Inverse correlation between ovarian development of Atlantic salmon (Salmo salar) smolts and sea age. Can. J. Fish. Aquat. Sci. 44: 1320-1325.

Chao, A., Gotelli, N. J., Hsieh, T. C., Sander, E. L., Ma, K. H., Colwell, R. K., and Ellison, A. M. 2014.

Rarefaction and extrapolation with hill numbers: a framework for sampling and estimation in species diversity studies. Ecol. Monogr. 84(1):45-67,

Chaput G. 2012. Overview of the status of Atlantic salmon (Salmo salar) in the North Atlantic and trends in marine mortality. ICES J. Mar. Sci. 69: 1538-1548. doi:10.1093/icesjms/fss013.

Chaput, G., and Benoît, H. P. 2012. Evidence for bottom-up trophic effects on return rates to a second spawning for Atlantic salmon (Salmo salar) from the Miramichi River, Canada. ICES J. Mar. Sci. 69: 16561667. https://doi.org/10.1093/icesjms/fss055

Chaput, G., Dempson, J. B., Caron, F., Jones R., and Gibson, R.J. 2006. A synthesis of life history characteristics and stock grouping of Atlantic salmon (Salmo salar L.) in eastern Canada. Canadian Science Advisory Secretariat. Research Document 2006/015. 
560

561

562

563

564

565

566

567

568

569

570

571

572

573

574

575

576

577

578

579

580

581

Consuegra, S., de García Leániz, C., Serdio, A., and Verspoor, E. 2005. Selective exploitation of early running fish may induce genetic and phenotypic changes in Atlantic salmon. J. Fish Biol. 67(Suppl A): 129-145.

Crozier, L. G., Hendry, A. P., Lawson, P. W., Quinn, T. P., Mantua, N. J., Battin, J., Shaw, R. G., and Huey, R. B. 2008. Evolutionary responses to climate change for organisms with complex life histories: Columbia River salmon as a case in point. Evol. Appl. 1: 252-270.

Erkinaro, J., Dempson, J.B., Julkunen, M., and Niemelä, E. 1997. Importance of ontogenetic habitat shifts to juvenile output and life history of Atlantic salmon in a large subarctic river: an approach based on analysis of scale characteristics. J. Fish Biol. 51: 1174-1185.

Erkinaro, J., Niemelä, E., Vähä, J.-P., Primmer, C. R., Brørs, S., and Hassinen, E. 2010. Distribution and biological characteristics of escaped farmed salmon in a major subarctic wild salmon river: implications for monitoring. Can. J. Fish. Aquat. Sci 67:130-142.

Erkinaro, J., Orell, P., Länsman, M., Falkegård, M., Kuusela, J., Kylmäaho, M., Johansen, N., Haantie, J. and Niemelä, E., 2017. Status of salmon stocks in the rivers Teno/Tana and Näätämöjoki/Neidenelva. ICES Working group on North Atlantic salmon. Working Document 15.

Fiske, P., Lund, R.A., and Hansen, L.P. 2005. Identifying fish farm escapees. In Stock identification methods, applications in fishery science. Edited by S.X. Cadrin, K.D. Friedland, and J.R. Waldeman. Elsevier Academic Press, Burlington, Mass. pp. 659-980.

Fleming, I. A. 1996. Reproductive strategies of Atlantic salmon: ecology and evolution. Rev. Fish Biol. Fish. 6: 379-416.

Frainer, A., Primicerio, R., Kortsch, S., Aune, M.,Dolgov, A. V., Fossheim, M., and Aschan, M. M. 2017.

Climate-driven changes in functional biogeography of Arctic marine fish communities. PNAS, 114: 1220212207. https://doi.org/10.1073/pnas.1706080114 
582

583

584

600

601

602

Friedland, K. D., MacLean, J. C., Hansen, L. P., Peyronnet, A. J., Karlsson, L., Reddin, D. G., Ó Maoiléidigh, N., and McCarthy, J. L. 2009. The recruitment of Atlantic salmon in Europe. ICES J. Mar. Sci. 66: 289-304.

Gaggiotti, O., and Vetter, R.D. 1999. Effect of life history strategy, environmental variability, and overexploitation on the genetic diversity of pelagic fish populations. Can. J. Fish. Aquat. Sci. 56: 1376-1388.

Gauthier-Ouellet, M., Dionne, M., Caron, F., King, T., and Bernachez, L. 2009. Spatiotemporal dynamics of the Atlantic salmon (Salmo salar) Greenland fishery inferred from mixed-stock analysis. Can J Fish Aquat Sci 66: 2040-2051.

Glebe, B. D., and Saunders, R. L. 1986. Genetic factors in sexual maturity of cultured Atlantic salmon (Salmo salar) parr and adults reared in sea cages. Can. Spec. Publ. Fish. Aquat. Sci. 89: 24-29.

Gjøen, H. M., and Bentsen H.B. 1997. Past, present and future improvement in salmon aquaculture. ICES J. Mar. Sci., 54: 1009-1014.

Greene, C. M., Hall, J. E., Guilbault, K. R., and Quinn, T. P. 2010. Improved viability of populations with diverse life-history portfolios. Biol. Lett. 6: 382-386.

Harvey, A. C., Tang, Y., Wennevik, V., Skaala, Ø., and Glover, K. A. 2017. Timing is everything: Fishing-season placement may represent the most important angling-induced evolutionary pressure on Atlantic salmon populations. Ecol. Evol. 7: 7490-7502.

Hátún, H., Payne, M.R., Beaugrand, G., Reid, P.C., Sand $\varnothing$, A.B., Drange H., Hansen B., Jacobsen, J.A., and Bloch, D. 2009. Large bio-geographical shifts in the north-eastern Atlantic Ocean: From the subpolar gyre, via plankton, to blue whiting and pilot whales. Prog. Oceanogr. 80: 149-162.

Heinimaa, S., and Erkinaro, J. 2004. Characteristics of mature male parr in the northernmost Atlantic salmon populations. J. Fish Biol. 64: 219-226. 
603

604

605

606

607

608

609

610

611

612

613

614

615

616

617

618

619

620

621

622

623

Heinimaa, S., and Heinimaa, P. 2004. Effect of the female size on egg quality and fecundity of the wild Atlantic salmon in the sub-arctic River Teno. Boreal Env. Res. 9: 55-62.

Hilborn, R., Quinn, T. P., Schindler, D. E., and Rogers, D. E. 2003. Biocomplexity and fisheries sustainability. Proc. Natl. Acad. Sci. 100: 6564-6568.

Hill, M. 1973. Diversity and evenness: a unifying notation and its consequences. Ecology 54: 427-432.

Hsieh, T. C. Ma K. H., and Chao, A. 2016. iNEXT: iNterpolation and EXTrapolation for species diversity. R package version 2.0.8, URL: http://chao.stat.nthu.edu.tw/blog/software-download

Hoegh-Guldberg, O., and Bruno, J.F. 2010. The Impact of Climate Change on the World's Marine Ecosystems. Science 328: 1523-1528.

Hutchings, J. A., and Jones. M. E. B. 1998. Life history variation and growth rate thresholds for maturity in Atlantic salmon, Salmo salar. Can. J. Fish. Aquat. Sci. 55(Suppl. 1): 22-47.

Hutchinson, W. F. 2008. The dangers of ignoring stock complexity in fishery management: the case of the North Sea cod. Biol. Lett. 4: 693-695 doi:10.1098/rsbl.2008.0443

ICES 2011. Report of the Workshop on Age Determination of Salmon (WKADS). ICES Document CM 2011/ACOM:44.

ICES 2017. Report of the Working Group on North Atlantic Salmon (WGNAS). ICES CM 2017/ACOM:20.

Järvi, T.H. 1948. On the periodicity of salmon reproduction in the Northern Baltic area and its causes. Rapports et procès-verbaux des réunions. Conseil Permanent Internationale pour L'Exploiration de la Mer. Charlottenlund, Danemark, 103 p.

Jensen, A. J., Zubchenko, A. V., Heggberget, T. G., Hvidsten, N. A., Johnsen, B. O., Kuzmin, O., Loenko, A. A., Lund, R. A., Martynov, V. G., Noesje, T. F., Sharov, A. F., and Økland, F. 1999. Cessation of the Norwegian 
624

625

626

627

628

629

630

631

632

633

634

635

636

637

638

639

640

641

642

643

644

drift net fishery: changes observed in Norwegian and Russian populations of Atlantic salmon. ICES J. Mar.

Sci. 56: 84-95.

Johnsen, K.-M. 2010. Registrering av stengsel og stågarn i Tanavassdraget 2010 - sammenstilling av registreringsdata fra 1984. LBT-rapport.

Jonsson, B., and Jonsson, N. 2011. Ecology of Atlantic salmon and brown trout: habitat as a template for life histories. Fish and Fisheries Series 33. Springer, London.

Jonsson, B., Jonsson, N., and Albertsen, J. 2016. Environmental change influences the life history of salmon Salmo salar in the North Atlantic Ocean. J. Fish Biol. 88: 618-637.

Jonsson, N., Hansen, L. P., and Jonsson, B. 1991. Variation in age, size and repeat spawning of adult Atlantic salmon in relation to river discharge. J. Anim. Ecol. 60: 937-947.

Jørgensen, C., Enberg, K., Dunlop, E. S., Arlinghaus, R., Boukal, D. S., Brander, K., Ernande, B., Gåtdmark, A., Johnston, F., Matsumura, S., Pardoe, H., Raab, H., Silva, A., Vainikka, A., Dieckmann, U., Heino, M., and Rijnsdorp, A. D. 2007. Managing evolving fish stocks. Science 318: 1247-1248.

Karlsson, S., Diserud, O.H., Fiske, P., and Hindar, K. 2016. Widespread genetic introgression of escaped farmed Atlantic salmon in wild salmon populations. ICES J. Mar. Sci. doi:10.1093/icesjms/fsw121

Klemetsen, A., Amundsen, P.-A., Dempson, J. B., Jonsson, B., Jonsson, N., O'Connell, M.F., and Mortensen, E. 2003. Atlantic salmon Salmo salar L., brown trout Salmo trutta L. and Arctic charr Salvelinus alpinus (L.): a review of aspects of their life histories. Ecol. Freshw. Fish 12: 1-59.

Kortsch, S., Primicerio, R., Fossheim, M., Dolgov, A. V., and Aschan, M. 2015. Climate change alters the structure of arctic marine food webs due to poleward shifts of boreal generalists. Proc. R. Soc. B 282: 20151546.http://dx.doi.org/10.1098/rspb.2015.1546 
645

646

647

648

649

650

651

652

653

654

655

656

657

658

659

660

661

662

663

664

665

666

667

Kuparinen, A., Hutchings, J. A., and Waples, R. S. 2016. Harvest-induced evolution and effective population size. Evol. Appl. 9: 658-672.

L'Abée -Lund, J. H., Vøllestad, L. A., and Beldring, S.. 2004. Spatial and temporal variation in the grilse proportion of Atlantic salmon in Norwegian rivers. Trans. Am. Fish. Soc. 133: 743-761.

Laugen, A. T., Engelhard, G. H., Whitlock, R., Arlinghaus, R., Dankel, D. J., Dunlop, E. S., Eikeset, A. M., Enberg, K., Jørgensen, C., Matsumura, S., Nusslé, S., Urbach, D., Baulier, L., Boukal, D. S., Ernande, B., Johnston, F. D., Mollet, F., Pardoe, H., Therkildsen, N. O., Uusi-Heikkilä, S., Vainikka, A., Heino, M., Rijnsdorp, A. D., and Dieckmann, U. 2014. Evolutionary impact assessment: accounting for evolutionary consequences of fishing in an ecosystem approach to fisheries management. Fish Fish. 15: 65-96.

Law, R., and Grey, D. R. 1989. Evolution of yields from populations with age-specific cropping. Evol. Ecol. 3: 343-359.

Lenth, R.V. 2016. Least-Squares Means: The R Package Ismeans. J. Stat. Softw. 69: 1-33. doi:10.18637/jss.v069.i01

Metcalfe, N.B., and Thorpe, J.E. 1990. Determinants of geographic variation in the age of seaward migrating salmon, Salmo salar. J. Anim. Ecol. 59: 135-145.

Moore, D. S., Chaput, G. J., and Pickard, P. R. 1995. The effects of fisheries on the biological characteristics and survival of mature Atlantic salmon (Salmo salar) from the Miramichi River. Can. Spec. Publ. Fish. Aquat. Sci. 123: 229-247.

Moore, J.W., McClure, M., Rogers, L.A., and Schindler, D.E. 2010. Synchronization and portfolio performance of threatened salmon. Cons. Lett. 3: 340-348.

Moore, J.W., Yeakel, J.D., Peard, D., Lough, J., and Beere, M. 2014. Life-history diversity and its importance to population stability and persistence of a migratory fish: steelhead in two large North American watersheds. J. Anim. Ecol. 83: 1035-1046. 
668

669

670

671

672

673

674

675

676

677

678

679

680

681

682

683

684

685

686

687

688

689

Myers, R. A., Hutchings, J. A., and Gibson, R. J. 1986. Variation in male parr maturation within and among populations of Atlantic salmon, Salmo salar. Can. J. Fish. Aquat. Sci. 43: 1242-1248.

Niemelä, E. 2004. Variation in the yearly and seasonal abundance of juvenile Atlantic salmon in a long term monitoring programme. Methodology, status of stocks and reference points. Doctoral dissertation. Acta Universitatis Ouluensis A 415 Oulu.

Niemelä, E., Erkinaro, J., Dempson, J. B., Julkunen, M., Zubchenko, A., Prusov, S., Svenning, M. A., Ingvaldsen, R., Holm, M., and Hassinen, E. 2004. Temporal synchrony and variation in abundance of Atlantic salmon in two subarctic Barents Sea rivers: influence of oceanic conditions. Can. J. Fish. Aquat. Sci. 61: $2384-2391$.

Niemelä, E., Erkinaro, J., Julkunen, M., and Hassinen, E. 2005. Is juvenile salmon abundance related to subsequent and preceding catches? Perspectives from a long-term monitoring programme. ICES J. Mar. Sci.

62: $1617-1629$

Niemelä, E., Erkinaro, J., Julkunen, M., Hassinen, E., Länsman, M., and Brørs, S. 2006a. Temporal variation in abundance, return rate and life histories of previously spawned Atlantic salmon in a large subarctic river. J. Fish Biol. 68: 1222-1240.

Niemelä, E., Orell, P., Erkinaro, J., Dempson, J. B., Brørs, S, Svenning, M., and Hassinen, E. 2006b. Previously spawned Atlantic salmon ascend a large subarctic river earlier than their maiden counterparts. J. Fish Biol. 69: 1151-1163.

Niemelä, E., Länsman, M., Hassinen, E., Brørs, S., Sandring, S., Johansen, M., and Muladal, R. 2009. Atlantin lohi (Salmo salar L.) Tenojoen vesistössä II; Saaliin kilomääräinen ja kappalemääräinen vaihtelu pyyntitavoittain ja saaliiden määriin vaikuttavia tekijöitä. Fylkesmannen i Finnmark, Miljøvernavdelingen, Rapport 6 - 2009. Available from 
690

691

692

693

694

695

696

697

698

699

700

701

702

703

704

705

706

707

708

709

710

711

712

https://www.fylkesmannen.no/Documents/Dokument\%20FMFI/Miljøvern/Rapportserie/2009_6\%20Atlanti n\%20lohi\%20Tenojoen\%20vesistossa\%202.pdf

Niemelä, E., Hassinen, E., and Kalske, T. 2012. Long-term salmon catches at sea in salmon districts in Finnmark. Kolarctic ENPI CBC - Kolarctic salmon project (KO197) - Report X. Available from https://prosjekt.fylkesmannen.no/Kolarcticsalmon/Documents/Reports/Scientific-reports/

Ohlberger, J., Ward, E. J., Schindler, D. E., and Lewis, B. 2018. Demographic changes in Chinook salmon across the Northeast Pacific Ocean. Fish Fish. DOI: 10.1111/faf.12272.

Olsen, E. M., Heino, J. Lilly, G. R., Morgan, M.J., Brattey, J., Ernande, B., and Dieckmann, U. 2004.

Maturation trends indicative of rapid evolution preceded the collapse of northern cod. Nature 428: $932-$ 935.

Otero, J., Jensen, A. J., L’Abée-Lund, J. H., Stenseth, N. C., Storvik, G. O., and Vøllestad, L. A. 2012. Contemporary ocean warming and freshwater conditions are related to later sea age at maturity in Atlantic salmon spawning in Norwegian rivers. Ecol. Evol. 2: 2197-2202. doi: 10.1002/ece3.337

Pasanen, L., Laukkanen-Nevala, P., Launonen, I., Prusov, S., Holmström, L., Niemelä, E., and Erkinaro, J. 2017. Extraction of sea temperature in the Barents Sea by a scale space multiresolution method - prospects for Atlantic salmon. J. Appl. Stat. 44: 2317-2336.

Perry, A.L., Low, P.J., Ellis, J.R., and Reynolds, J.D. 2005. Climate change and distribution shifts in marine fishes. Science 308: 1912-1915.

R Core Team. 2015. R: a language and environment for statistical computing. R Foundation for Statistical Computing, Vienna, Austria. URL http://www.R-project.org/.

Reid, J. E. and Chaput G. 2012. Spawning history influence on fecundity, egg size, and egg survival of Atlantic salmon (Salmo salar) from the Miramichi River, New Brunswick, Canada. ICES J. Mar. Sci. 69: 16781685. 
713

714

715

716

717

718

719

720

721

722

723

724

725

726

727

728

729

730

731

732

Rogers, L. A., and Schindler, D. E. 2008. Asynchrony in population dynamics of sockeye salmon in southwest Alaska. Oikos 117: 1578-1586.

Saunders, R. L., and Schom, C. B. 1985. Importance of the variation in life history parameters of Atlantic salmon. Can. J. Fish. Aquat. Sci. 42: 615-618

Schaffer, W. M., and Elson, P. E. 1975. The adaptive significance of variations in life history among local populations of Atlantic salmon in North America. Ecology 56: 577-590

Schindler, D. E., Hilborn, R., Chasco, B., Boatright, C. P., Quinn, T. P., Rogers, L. A., and Webster, M. S. 2010. Population diversity and the portfolio effect in an exploited species. Nature 465: 609-612.

Shearer. W. M. 1992. The Atlantic Salmon: Natural History, Exploitation and Future Management. Oxford: Fishing News Books.

Stearns, S. C. 1992. The evolution of life histories. Oxford: Oxford University Press.

Strothotte, E., Chaput, G. J., and Rosenthalt, H. 2005. Seasonal growth of wild Atlantic salmon (Salmo salar L.) juveniles and implications on age at smoltification. J. Fish Biol. 67: 1585-1602.

Studenov, I. Antonova,V. P., Chuksina, N. A., and Titov, S. F. 2008. Atlantic salmon (Salmo salar Linnaeus, 1758) of the Pechora River. SevPINRO, Arkhanlgesk, Russia.

Thorley, J. L., Eatherley, D. M. R., Stephen, A. B., Simpson, I., MacLean, J.C., and Youngson, A. F. 2005. Congruence between automatic fish counter data and rod catches of Atlantic salmon ( Salmo salar ) in Scottish rivers, ICES J. Mar. Sci. 62: 808-817. https://doi.org/10.1016/j.icesjms.2005.01.016

Thorpe, J.E. 1998. Salmonid life-history evolution as a constraint on marine stock enhancement. Bull. Mar. Sci. 62: 465-475. 
733

734

735

736

737

738

739

740

741

742

743

744

Uusi-Heikkilä, S., Whiteley, A. R., Kuparinen, A., Matsumura, S., Venturelli, P. A., Wolter, C., Slate,. J., Primmer, C., Meinelt, T., Killen, S. S., Bierbach, D., Polverino, G., Ludwig, A., and Arlinghaus, R. 2015. The evolutionary legacy of size-selective harvesting extends from genes to populations. Evol. Appl. 8: 597-620.

Vähä, J.-P., Erkinaro, J., Niemelä, E., and Primmer, C. 2007. Life-history and habitat features influence the within-river genetic structure of Atlantic salmon. Mol. Ecol. 16: 2638-2654.

Vähä, J.-P., Erkinaro, J., Niemelä, E., and Primmer, C. 2008. Temporally stable genetic structure and low migration in an Atlantic salmon population complex: implications for conservation and management. Evol. Appl. 1: 137-154.

Vähä, J.-P., Erkinaro, J., Niemelä, E., Primmer, C.R., Saloniemi, I., Johansen, M., Svenning, M., and Brørs, S. 2011. Temporally stable population-specific differences in run timing of one-sea-winter Atlantic salmon returning to a large river system. Evol. Appl. 4: 39-53.

Vähä, J.P., Erkinaro, J., Falkegård, M., Orel,I P., and Niemelä, E. 2017. Genetic stock identification of Atlantic salmon and its evaluation in a large population complex. Can. J. Fish. Aquat. Sci. 74: 327-338.

Whoriskey, F.G., Kuzhmin, O. and Goodhart, D. 1996. Monitoring of sports fishing catches of Atlantic Salmon (Salmo salar L.) of the Ponoi River, Russia to document population characteristics. Pol. Arch. Hydrobiol. 43: 167-177.

Wood, S.N. 2011. Fast stable restricted maximum likelihood and marginal likelihood estimation of semiparametric generalized linear models. J. R. Stat. Soc.(B) 73: 3-36

Youngson, A. F., Maclean, J. C., and Fryer, R. J. 2002. Rod catch trends for early-running MSW salmon in Scottish rivers (1952-1997): divergence among stock components. ICES J. Mar. Sci. 59: 836-849. 
755

https://mc06.manuscriptcentral.com/cjfas-pubs 
Table 1. Significance of variables included in the analyses of Atlantic salmon sea-age distribution 759 in the River Teno system. Results for single variables included in significant interactions are not 760 displayed. Df, degree of freedom; NS, non-significant relationship; $p$-values: ${ }^{*}<0.05, * *<0.01$, 761

762 $* * *<0.001$ )

\begin{tabular}{|c|c|c|c|c|c|c|c|c|c|}
\hline \multirow[t]{2}{*}{ Quasi-binomial models } & \multirow[b]{2}{*}{$\mathrm{df}$} & \multicolumn{2}{|c|}{1 sea winter } & \multicolumn{2}{|c|}{2 sea winter } & \multicolumn{2}{|c|}{3 sea winter } & \multicolumn{2}{|c|}{ Previous spawners } \\
\hline & & F-value & Significance & F-value & Significance & F-value & Significance & F-value & Significance \\
\hline \multicolumn{10}{|l|}{ Single variables } \\
\hline Year & 1 & - & - & - & - & 207,1 & $* * *$ & - & - \\
\hline Location & 8 & - & - & - & - & 172,7 & $* * *$ & - & - \\
\hline Fishing gear & 3 & 77,7 & $* * *$ & 11,1 & $* * *$ & 64,4 & $* * *$ & 107,0 & $* * *$ \\
\hline $\operatorname{Lag} Y$ & 1 & 316,3 & $* * *$ & 65,3 & $* * *$ & 142,1 & $* * *$ & 128,0 & $* * *$ \\
\hline Sex & - & - & - & - & - & - & - & - & - \\
\hline Month & - & - & - & - & - & - & - & - & - \\
\hline \multicolumn{10}{|l|}{ Interaction terms } \\
\hline Year : sex & 1 & 19,7 & $* * *$ & 23,5 & $* * *$ & 1,4 & NS & 0,4 & NS \\
\hline Year : location & 8 & 6,3 & $* * *$ & 1,1 & NS & 1,5 & NS & 3,2 & $* *$ \\
\hline Sex : location & 8 & 2,7 & $* *$ & 6,4 & $* * *$ & 0,4 & NS & 2,1 & $*$ \\
\hline Sex : month & 2 & 4,5 & * & 9,7 & $* * *$ & 81,2 & $* * *$ & 39,6 & $* * *$ \\
\hline Year : sex : location & 8 & 0,6 & NS & 1,1 & NS & 0,5 & NS & 1,0 & NS \\
\hline
\end{tabular}

763

764

765

766

767

768

769

770

771

772 


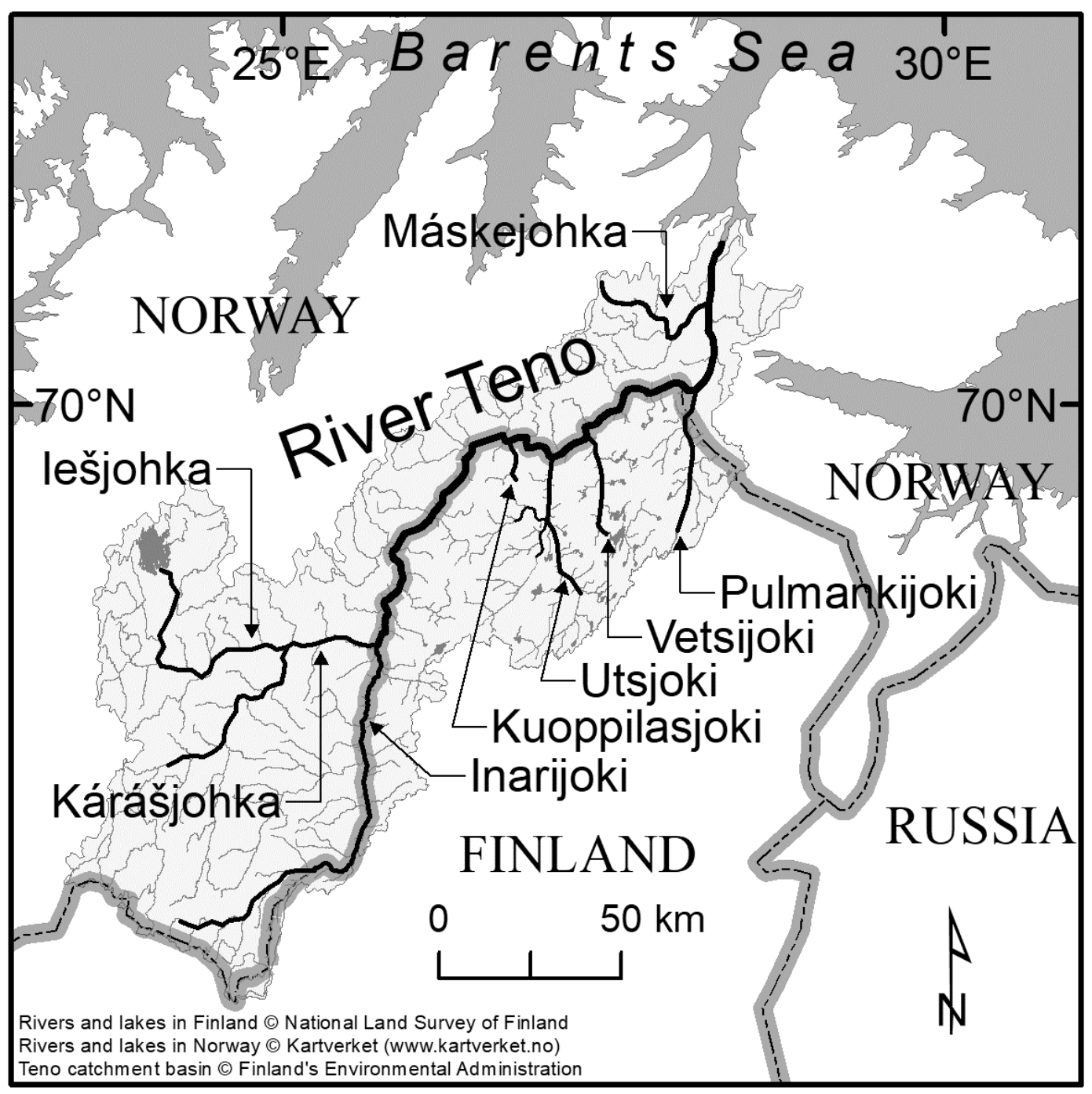

Fig. 1. The River Teno system in northernmost Europe. The Teno main stem, as referred to in this study, is the river stretch from the confluence of the headwater tributaries Inarijoki and Kárášjohka to the Barents Sea. 


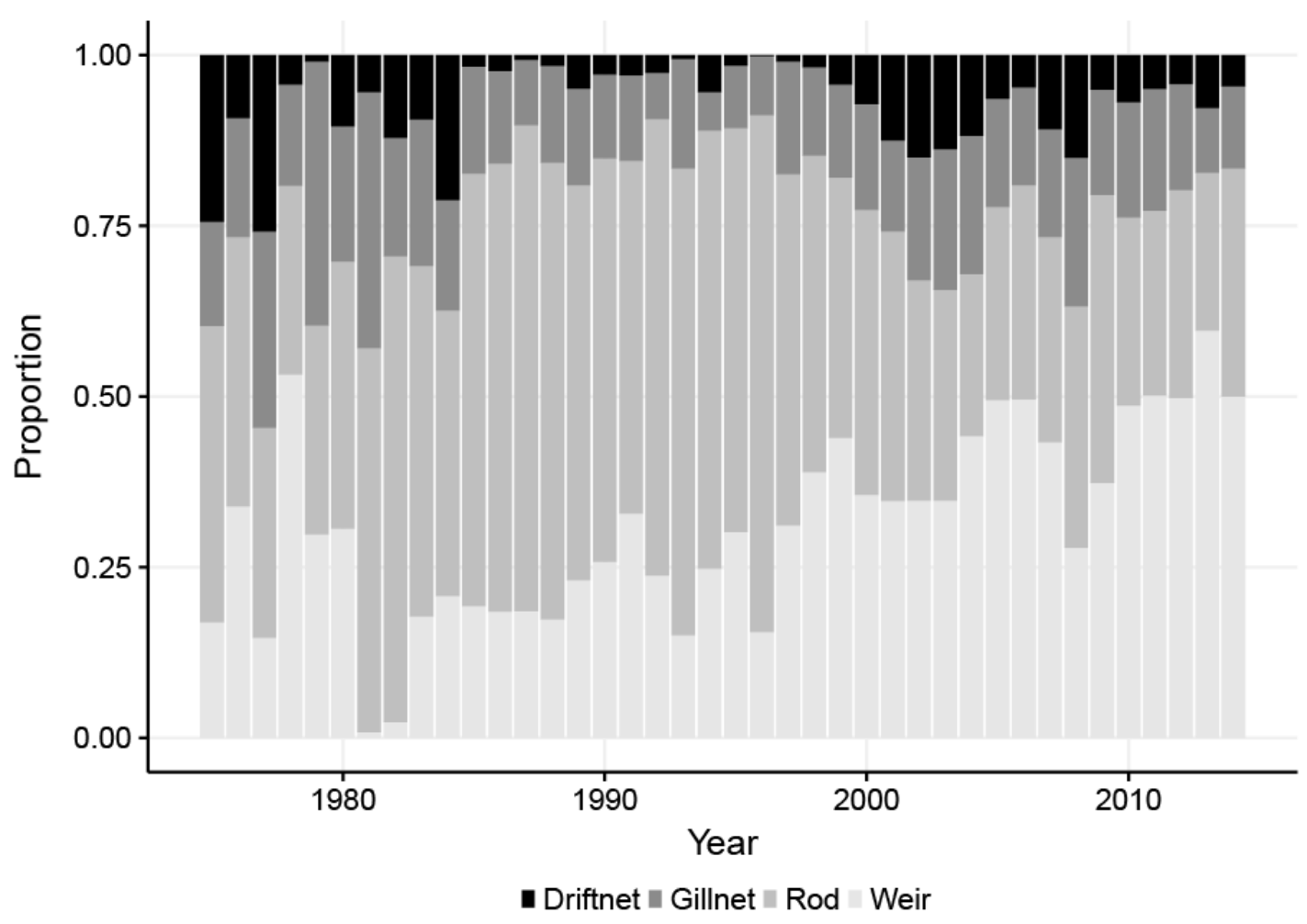

786 Fig. 2. Proportions of samples collected between different fishing gear types in the Teno main 787 stem fisheries across the study period. 

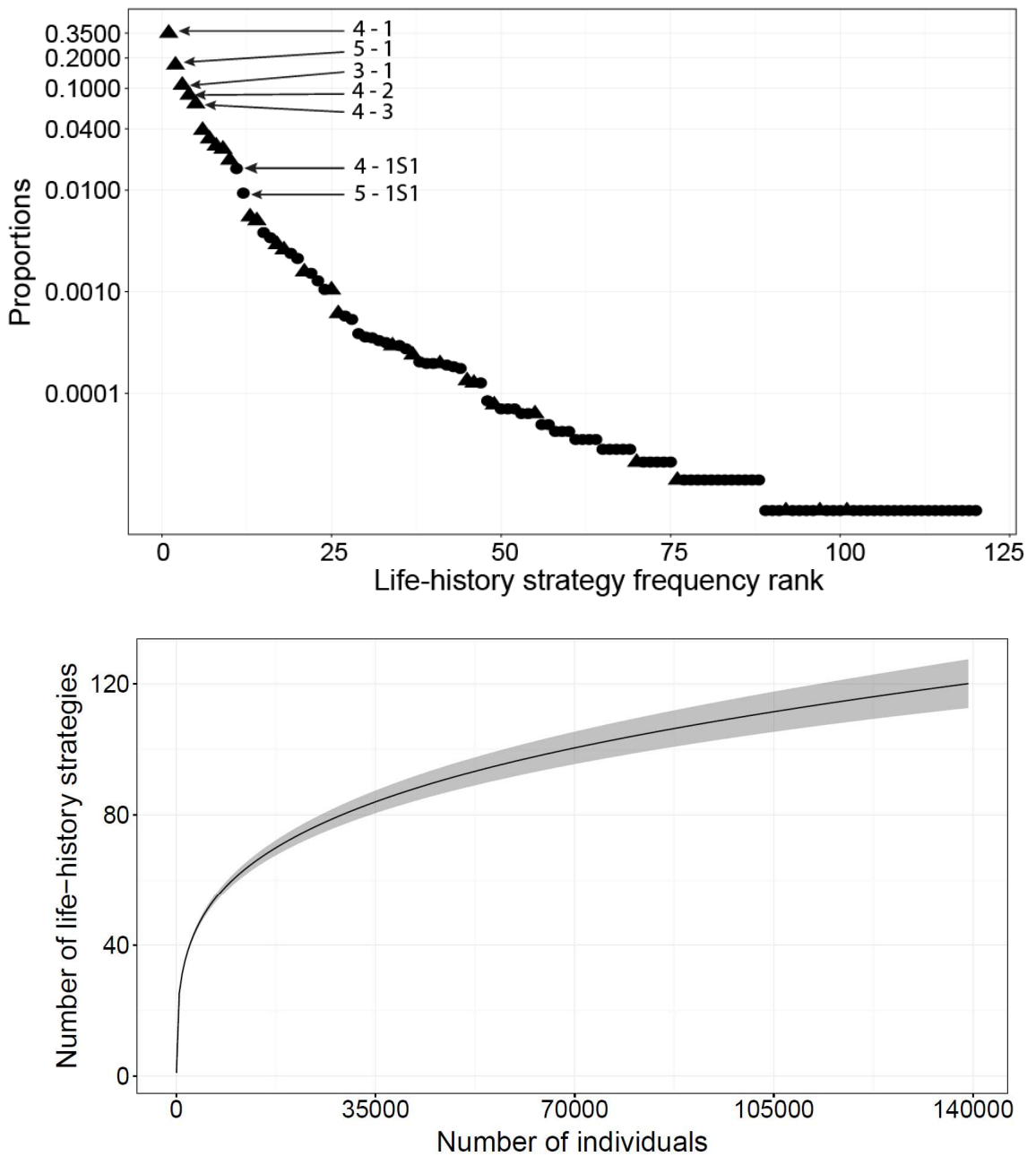

791

792

793

794

795

796

797

798

799

800
Fig. 3. Proportion of each life history strategy of Teno salmon ranked by their frequency in catches (upper panel, triangles: maiden salmon; circles: previous spawners). Five and two most common strategies have been indicated for maiden salmon (e.g. 4-1: four years in freshwater, one year at sea) and previous spawners (e.g. 4-1S1: four years in freshwater, one year at sea, first spawning migration, one year at sea, second spawning migration), respectively. Rarefaction curve of the number of strategies for the 40 years sampling period (lower panel, shaded area represents $95 \%$ unconditional confidence interval). 
801

802

803

804

805

806

807

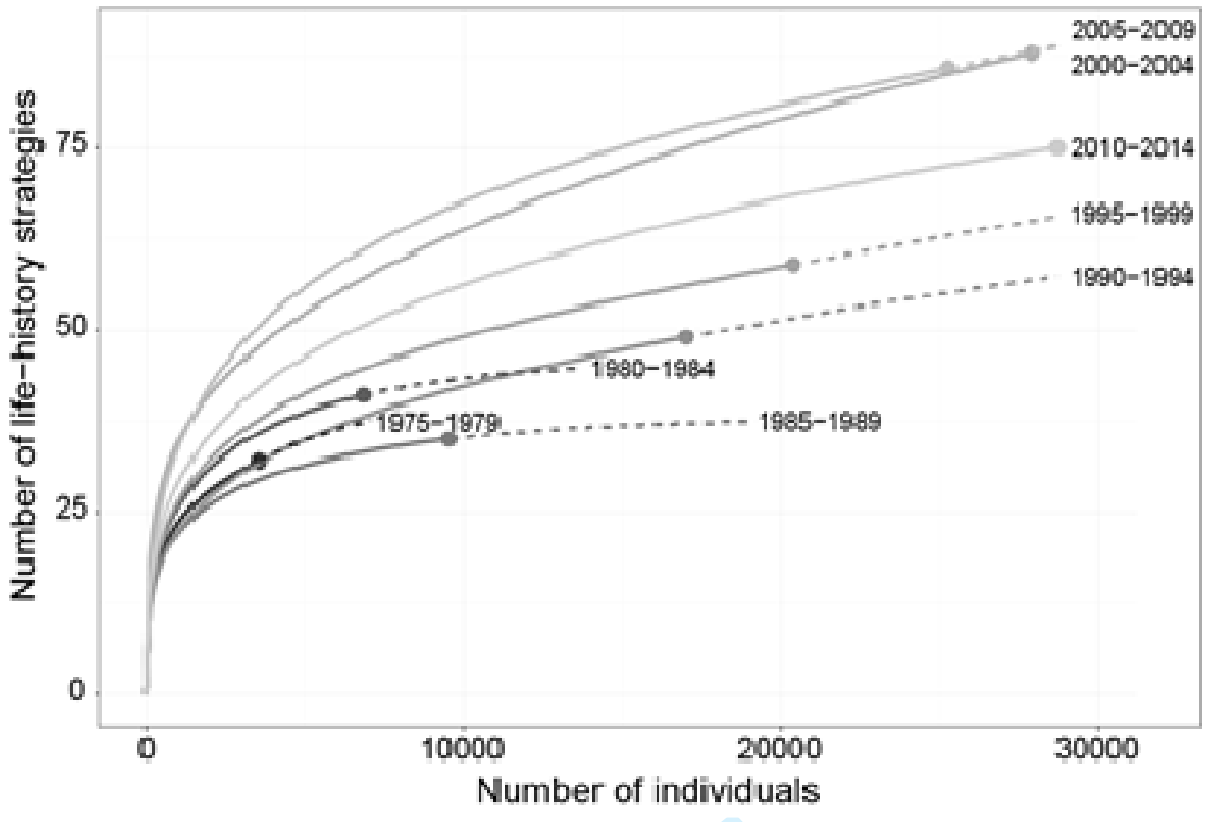

Fig. 4. Individual-based rarefaction (solid lines) and extrapolation (dashed lines) plot of the life history richness of each 5-year period between 1975 and 2014. 

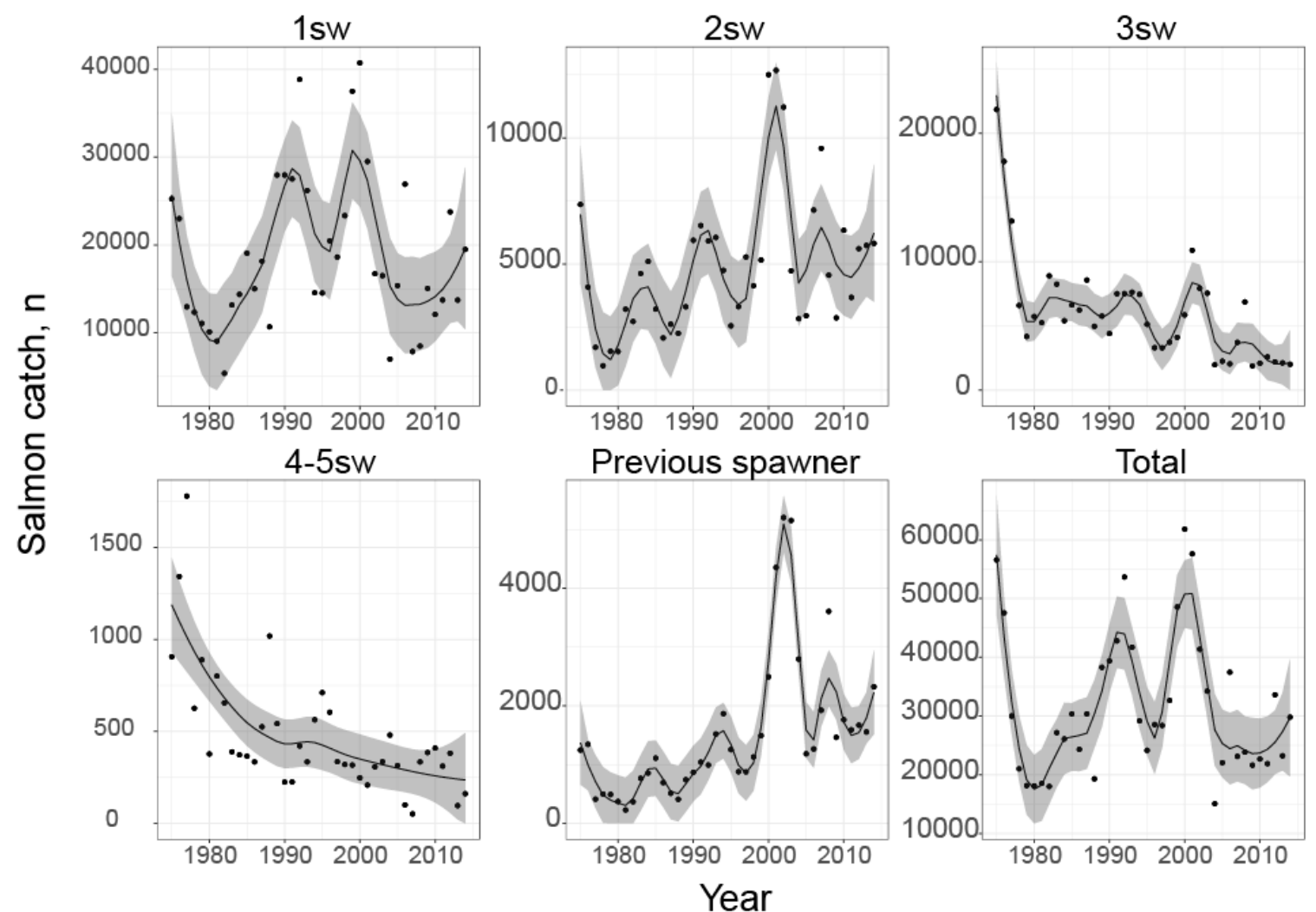

810

811 Fig. 5. Estimated annual catches of salmon in the Teno river system in different sea age groups (1812 3SW, 4-5SW combined, previous spawners) in 1975-2014. Lines represent LOESS regressions with 813 degrees of smoothing minimizing AICC; $95 \%$ confidence intervals are indicated with shaded areas 
814

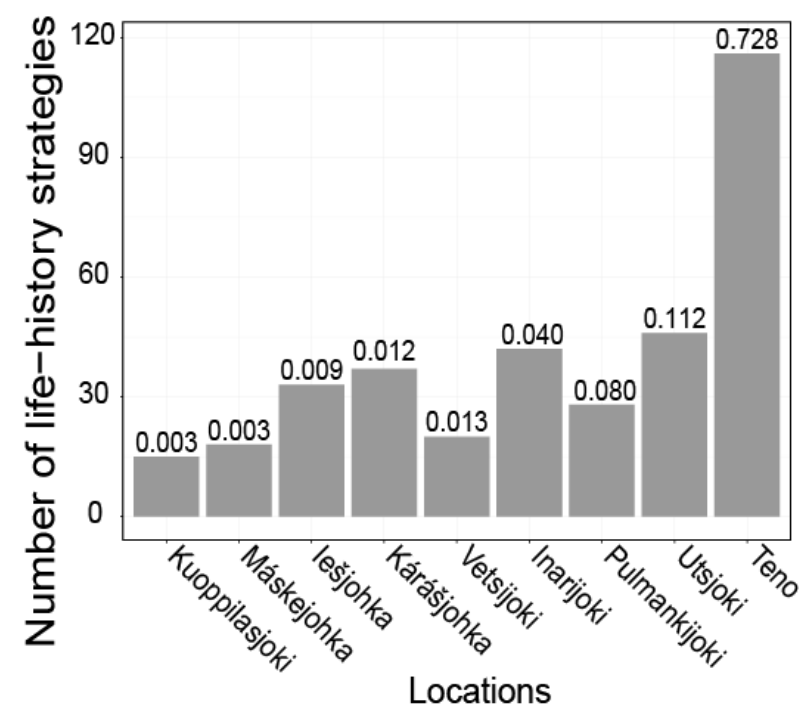

Fig. 6. Barplot of the number of life-history strategies described (left) and the estimated Hill numbers (right; life history strategy diversity corrected for sampling effort) in different locations of the Teno river system. Locations are ordered from the left to the right according to the proportion of samples collected (figures above bars on left graph). Error bars on the right graph indicate $95 \%$ 


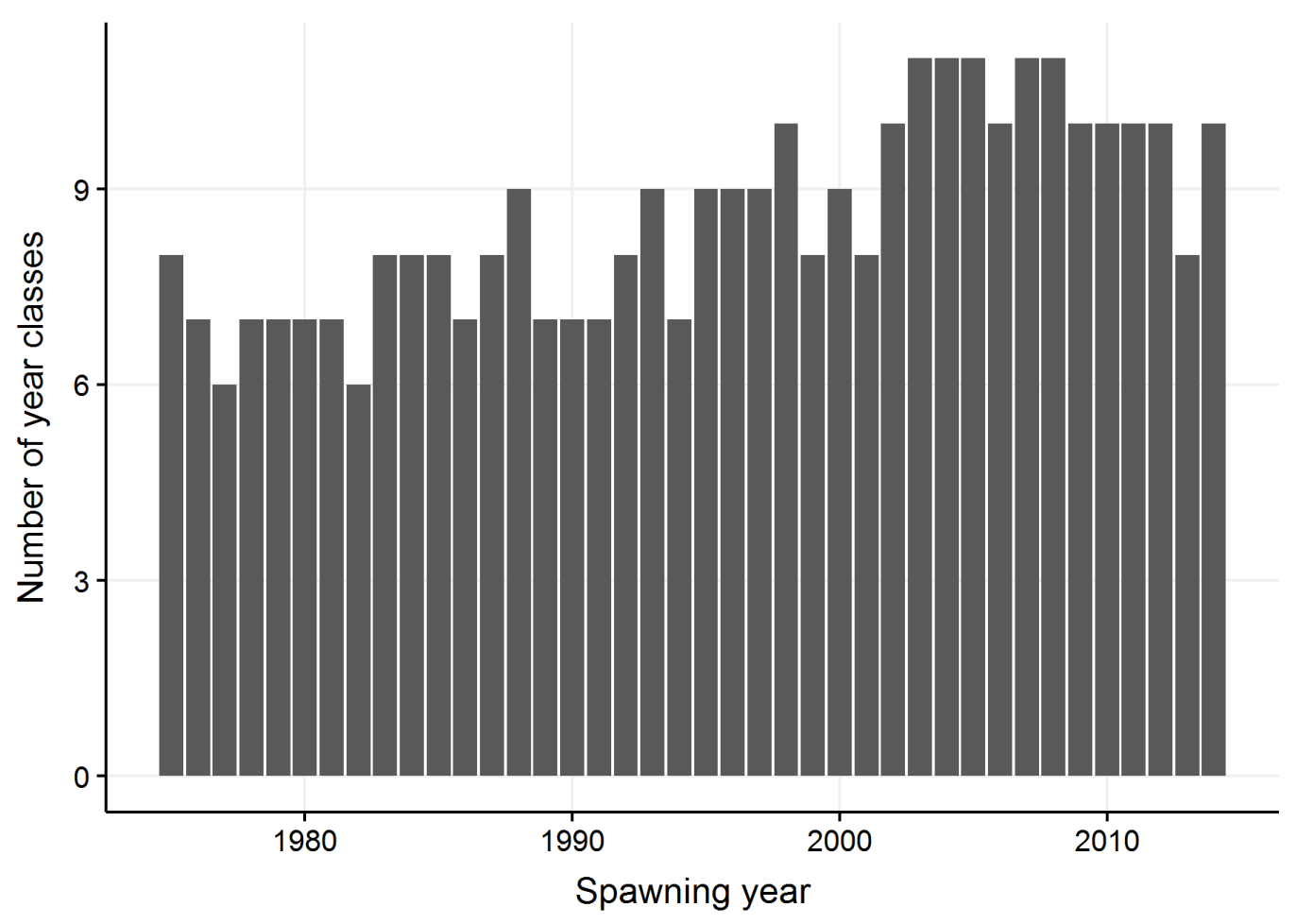

828

Fig. 7. Number of year classes from individual hatching years in yearly Atlantic salmon catch 830 samples (spawning year) collected from the Teno main stem fisheries. 

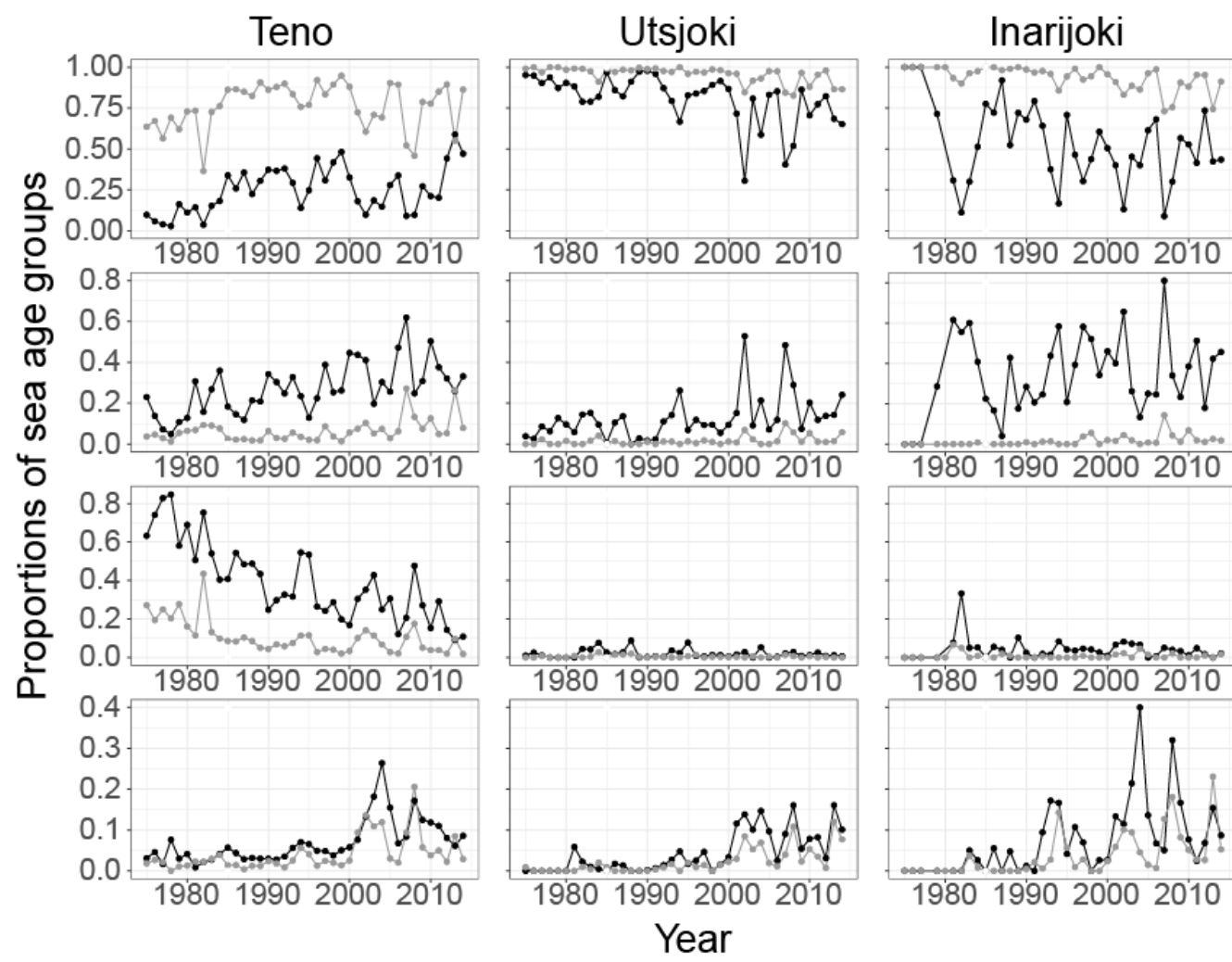

$1 \mathrm{SW}$

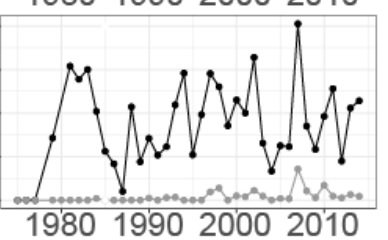

2SW

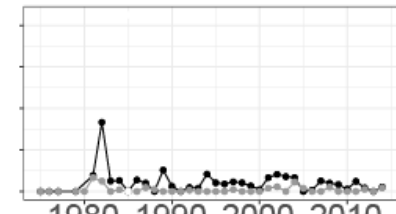

3SW

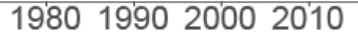

Previous

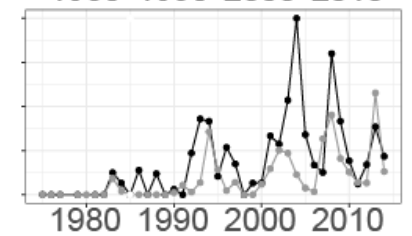

spawners

835

836

837

Fig. 8. Temporal variation in proportions of 1-3SW maiden salmon and previous spawners in two tributaries (Utsjoki and Inarijoki) and the main stem (Teno) of the River Teno system (see Fig. 1 for

839 locations). Yearly proportions in each river sum up to 1.0 separately for males (grey) and females

840 (black).

841

842

843

844 

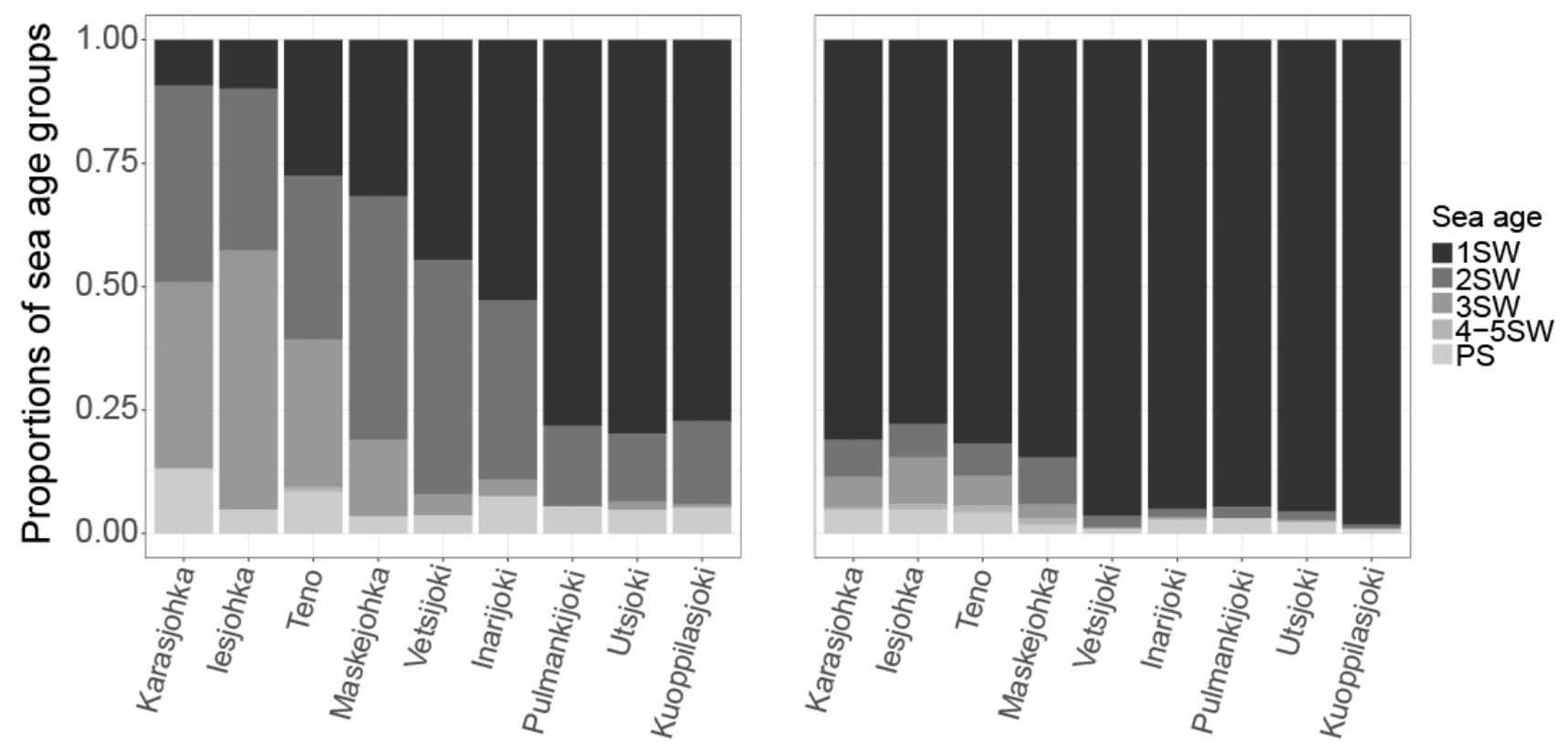

850 Fig. 9. Proportions of the different sea ages of females (left) and males (right) in catches from 851 different parts of the Teno river system (see Fig. 1 for details). 1-5SW, one- to five-sea-winter 852 salmon; PS, previous spawners.

853

854 


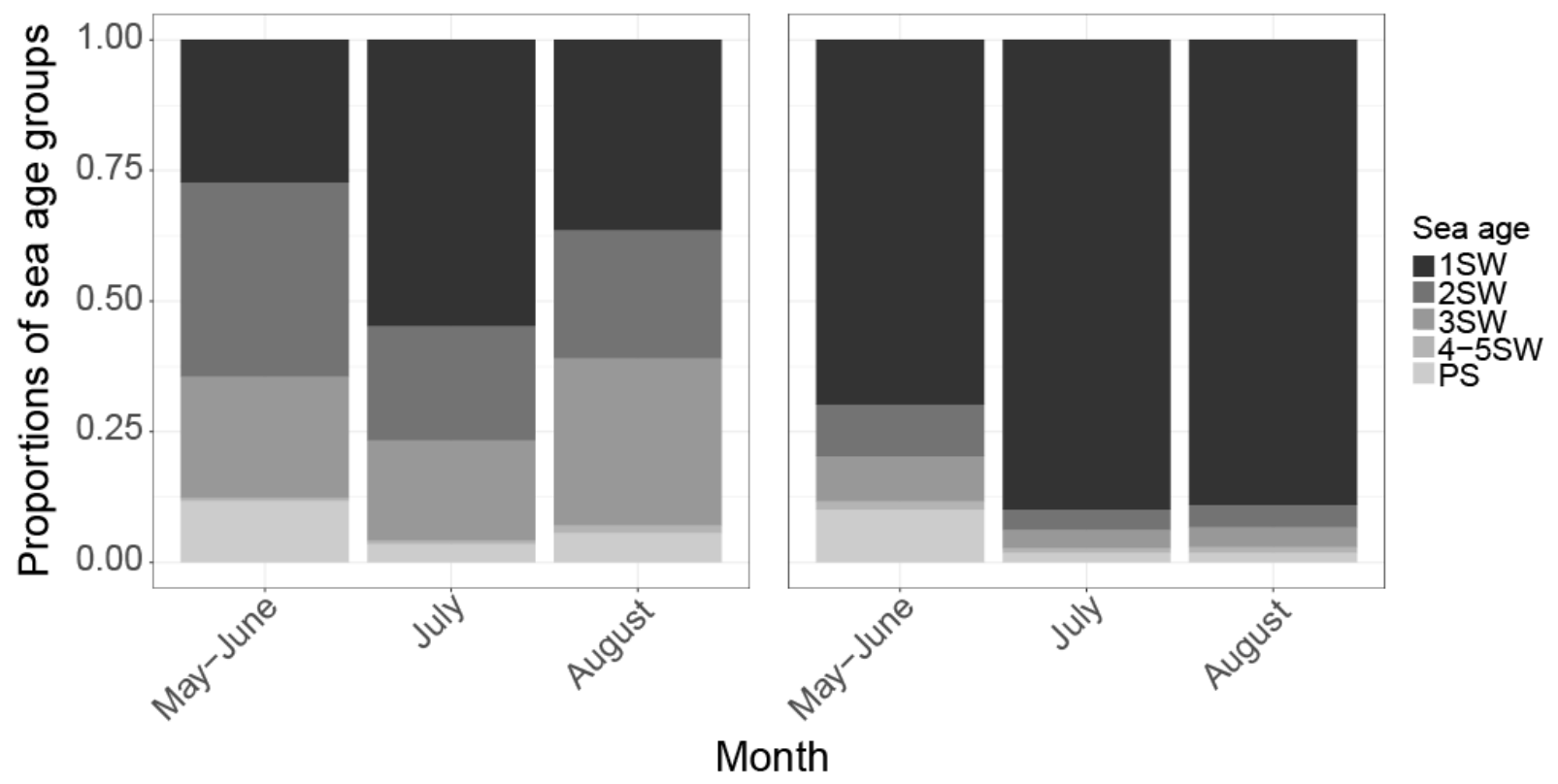

Fig. 10. Sea-age distribution of female (left) and male (right) Atlantic salmon in catches obtained in different months in the River Teno system. 1-5SW, one- to five-sea-winter salmon; PS, previous spawners.

859

860

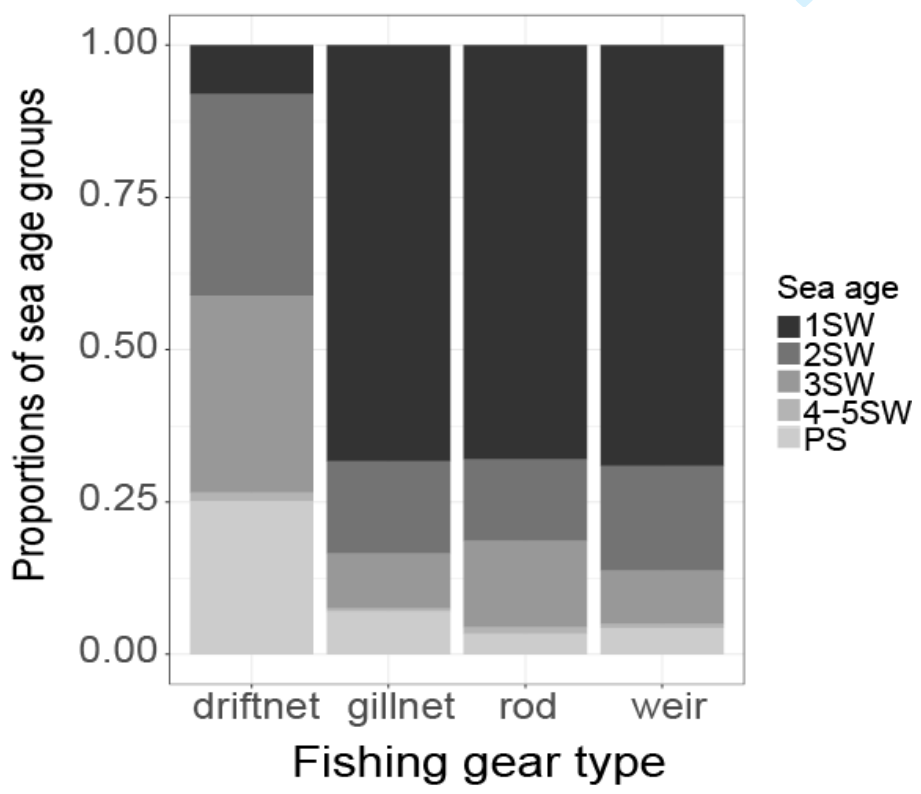


874

875

876

877

878

879

880

881

882

883

884

885

886

887

888

889
Fig. 11. Sea-age distribution of Atlantic salmon captured by different fishing gears in the main stem of the River Teno. 1-5SW, one- to five-sea-winter salmon; PS, previous spawners.

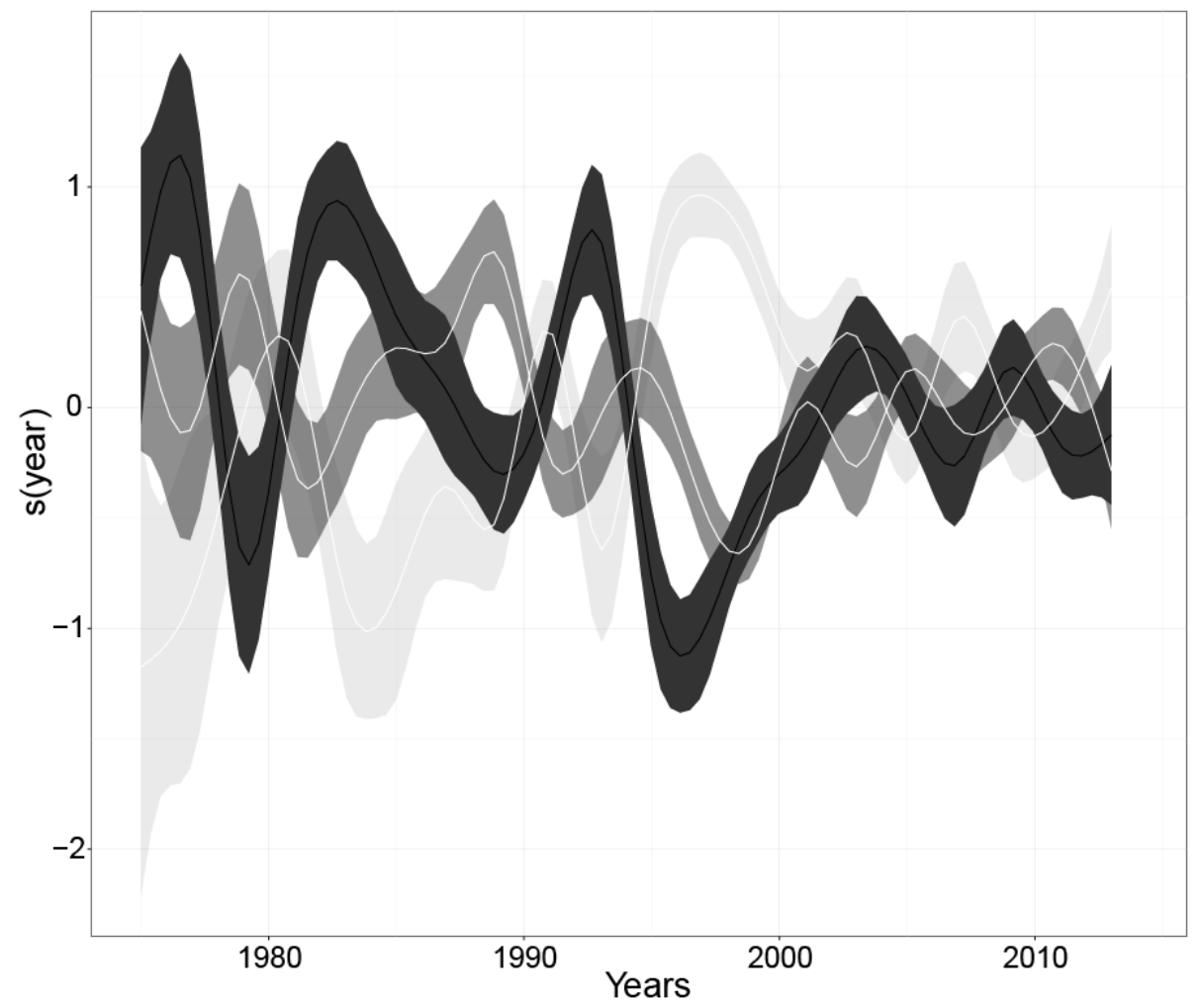

Fig. 12. Partial GAM plot representing the effects of years on the proportion of three- (black), four(dark grey), and five- (light gray) year-old smolts in catch samples from the River Teno. Y-axis represents the contribution of the smoother. The shaded regions are $95 \%$ confidence bands around the curve. 
890

891

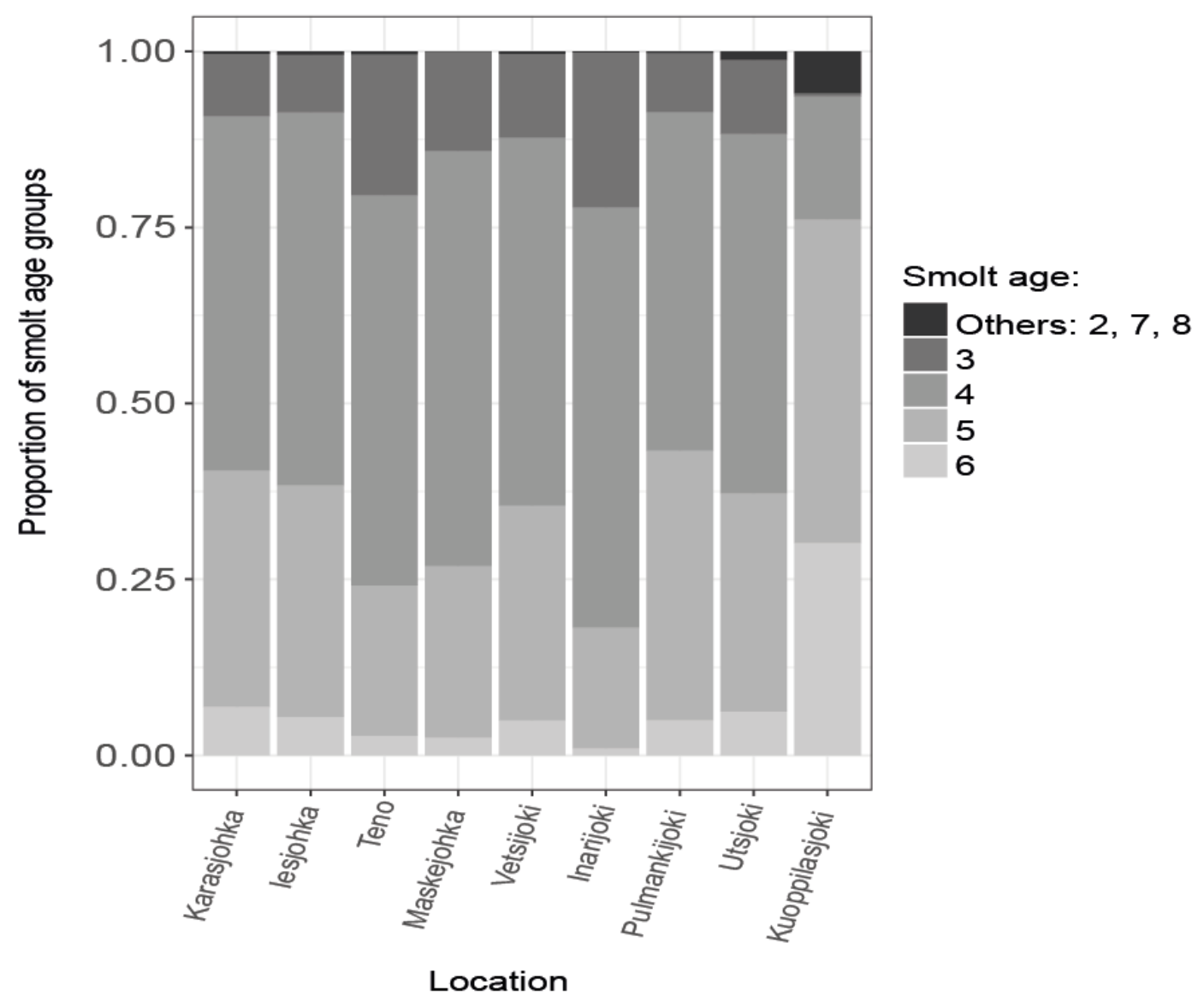

892

893 Fig. 13. Proportions of the different smolt ages of adult returning salmon captured from different 894 parts of the Teno river system (see Fig. 1 for locations).

895

896 
897

898

899

900

901

902

903

904

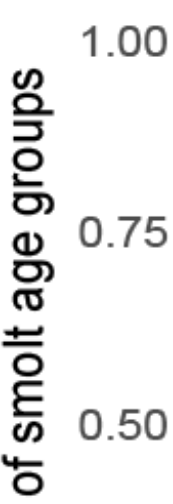

은
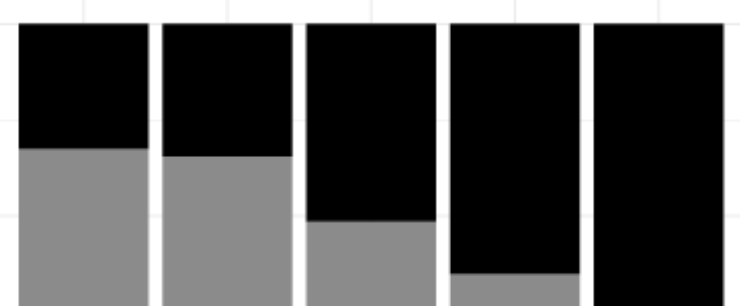

905

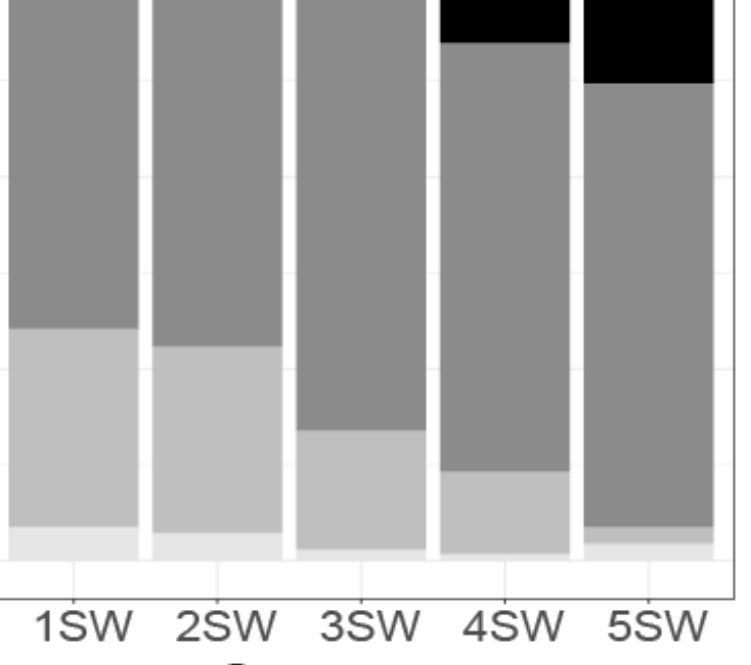

Sea age groups

906

907 Fig. 14. Proportions of Atlantic salmon in the River Teno system that have smoltified after three

908 (black), four (grey) and five years (light grey) in relation to their sea-age. Other smolt ages $(2,6-8)$

909 are indicated by the lightest grey. 